\title{
The Way to the Rocks-Changes of Networks of Hiking Trails in Chosen Sandstone Landscapes in Poland and the Czech Republic in the Period of Political Transformation
}

\author{
Krzysztof Kołodziejczyk ${ }^{1}$ (D)
}

Received: 30 November 2018 / Accepted: 7 January 2020 / Published online: 10 February 2020

(C) The Author(s) 2020

\begin{abstract}
The political transformation taking place in Central European countries at the turn of 1980s and 1990s influenced, among other aspects, the methods of nature protection and making it available for tourism. The changes taking place at that time have been traced in the article on the example of three sandstone landscapes, which belong to the most popular geotouristic attractions of the Czech Republic and Poland: Prachov Rocks Nature Reserve with adjacent fragments of the Bohemian Paradise Protected Landscape Area, Adršpach-Teplice Rocks National Nature Reserve and the Table Mountains National Park. These changes were analysed on the basis of transformations of the networks of hiking trails and development of other tourism facilities within the boundaries of the protected areas. Analysis covers the entire period from the end of communism (1980s) up to present days. According to the study, in the case of all analysed protected areas, the systemic transformation in Central Europe played an important role as a factor affecting the network of hiking trails. In each case, however, local factors were also important. The biggest changes occurred in the Adršpach-Teplice Rocks and the Table Mountains. In the first case, the number and distribution of visitors needed to be controlled, leading to modification of route network. The main reason of its significant reduction was to separate paid routes from those not charged. In the Table Mountains, the network was substantially developed as a consequence of the establishment of a national park there and the political changes at the turn of twentieth and twenty-first centuries which opened the border zone and forced the marking of new tourist trails. In the Prachov Rocks, the existing layout of hiking trails has been largely kept unchanged because the continuous intensive tourist traffic did not allow any reductions, even if these would help to protect the environment. On the other hand, the network was really well developed, that it did not require further growth. Today's networks of tourist trails in the Prachov Rocks and some parts of the Table Mountains seem too developed, taking into account the protective regime of both areas. In terms of interpretation of geoheritage, the most extensive and targeted offer can be found in the Table Mountains National Park. Referring to the methods used, the graph theory cannot be applied easily to tourist trails networks, especially when a dissected landscape is analysed. A simple but very helpful indicator illustrating the development of the network is the density of tourist trails per square kilometre.
\end{abstract}

Keywords Sandstone landscapes $\cdot$ Protected areas $\cdot$ Hiking trails $\cdot$ Graph theory $\cdot$ Poland $\cdot$ Czech Republic

\section{Introduction}

As a result of political changes at the turn of the 1980 s and 1990 s, the countries of Central Europe, hitherto under the in-

Krzysztof Kołodziejczyk

krzysztof.kolodziejczyk@uwr.edu.pl

1 Department of Regional Geography and Tourism, Institute of Geography and Regional Development, University of Wroclaw, Uniwersytecki square 1, 50-137 Wroclaw, Poland fluence of the Union of Soviet Socialist Republics, began to undergo system-wide transformation (Gilejko 2009; Illner 1996; Klaus 2006; Roszkowski 2003). These include Poland and the Czech Republic (which was created in 1993 as a consequence of the breakup of Czechoslovakia, formally Czech and Slovak Federal Republic and earlier Czechoslovak Socialistic Republic) discussed in this article. The changes covered, among others, the ownership of the land, which in the socalled Socialist countries was nationalised in the 1950s to a huge extent (however, small lands remained private in both analysed countries). From the 1990s - to a different extent in 
individual countries - the land was either returned to their former owners or transferred to private owners, social organisations (including church) and companies on various terms, but in both Poland and the Czech Republic, a significant portion of land, mostly forests and protected lands, are still owned by the state. Countries began to operate on the basis of free market principles. An important consequence of these processes was a change in the approach to nature conservation (KluvánkováOravská et al. 2009; Pavlínek and Pickles 2005), which is connected, among others, with the decentralisation of power and the transfer of some of the responsibilities in this area to the regional and local level, but also with a change in the perception of the natural environment by society. An expression of this was, firstly, the creation of new forms of nature protection (in Poland, apart from the most popular national and landscape parks, the category of areas under ecological use or documentation stands appeared, later also Natura 2000 sites, while in the Czech Republic, the category of natural park was added), secondly, establishing new protected areas of the already existing types and increasing their aerial extent (e.g. the Table Mountains National Park-discussed in this workwas created in 1993 (Kasprzak and Skoczylas 1993; Lijewski et al. 2002)). In the Czech Republic, the area covered by various forms of protection increased significantly during this period. It is enough to mention that the only existing national park in this country-Giant Mountains (Czech Krkonoše) created in 1963 - was complemented in 1991 by the Šumava and Podyjí national parks, and in 1999-by the National Park Czech Switzerland (Czech České Švýcarsko (Vystoupil and Šauer 2012)). Also, many lower-order areas were created, mainly areas of protected landscape and natural monuments. In recent years, geoparks are being created, being part of national, European and global networks. ${ }^{1}$ In the article, these issues are analysed for areas important for their geoheritage, and from the perspective of changes in tourist trails offer, which is a novelty comparing to other current works.

Political transformation also meant changes in tourism sector - a reduction of the role of social and mass tourism in favour of individual trips (Lijewski et al. 2002; Vystoupil and Šauer 2012), more and more often abroad (due to the opening of borders). The role of national tourist organisations was limited - in Poland it was the case of the Polish Tourist and Sightseeing Society (Polish Polskie Towarzystwo Turystyczno-Krajoznawcze, PTTK), and in the Czech Republic_liquidated Czechoslovak Association of Physical Education (Czech Československý svaz, tělesné vychovy) and the reviving in that time Club of Czech Tourists (Czech Klub českých turistů). It is worth emphasising, however, that the last mentioned association managed to maintain full control over

\footnotetext{
${ }^{1}$ The Prachov Rocks are a part of the Bohemian Paradise Geopark, and the Adršpach-Teplice Rocks a part of the Broumov Geopark, referring to the areas analysed in the text.
}

hiking trails in the whole country (and partial over ski and bicycle routes), guaranteed by state law (Vystoupil and Šauer 2012), which was not successful in Poland. Tourist trips were no longer so much organised by central authorities or workplaces, but mostly by individual tourists themselves or by travel agencies (however the latter is more common in case of international tourism), which had to result in changes in the accommodation and catering facilities. In that period also the preferences of people evolved. Before 1989, people had little chance to travel abroad due to formal limitations connected with making a passport, crossing national border or even staying in the border zone (Kołodziejczyk 2014a). Therefore, homeland tourism was the dominant tourist destination (Lijewski et al. 2002). In addition, in the Czech Republic for many people, the individual tourism was a way of psychological emigration, running away from cities where strict control by communist authorities was common. This resulted in the development of second homes (Bičík 2001; Vágner 2001), much more intensive prior 1989 in the Czech Republic than in Poland (Kowalczyk 1994; Matczak 1986). In 1990, the boarders opened (Dołzbłasz 2017). Everyone wanted to travel abroad and build own carrier. Therefore, there was no time to discover homeland, domestic tourism was in regression and many potentially attractive destinations were visited by single tourists. However, since 2000, people returned to homeland tourism, commonly combining main foreign vacations with homeland trips during the rest of the year. Number of homeland visitors dramatically increased (Vystoupil and Šauer 2012) and therefore appropriate visitor management is required (Potocki 2010).

Changes in the field of nature conservation and tourism development have left their mark on the network of tourist trails. The beginning of the 1990s was the period when their network underwent significant changes, particularly strong in protected areas. However, transformations are not always unambiguous. Theoretically, the inclusion of an area within the boundaries of a national park should result in restricting accessibility for tourists. However, at the same time, the area becomes more attractive, which forces local authorities to create new tourist infrastructure, including trails, in order to direct the increased tourist traffic. When looking at various protected areas, at the turn of the twentieth and twenty-first centuries, both development and limiting of the offer of trails can be noticed. This is the result of the fact that many factors, other than the nature protection regime, influence the network of tourist trails, both of natural and anthropogenic character (Table 1).

The multiplicity of factors affecting the network of tourist routes means that a universal model of its development in protected areas cannot be determined. In the article, these relationships will be shown on the example of three regions extremely popular among both homeland and foreign tourists, covered by various forms of nature conservation. They are 
Table 1 Factors influencing changes of the networks of tourist trails in protected areas

\begin{tabular}{|c|c|}
\hline Factors & Examples of relevant references \\
\hline Type of terrain (relief, wetlands) & $\begin{array}{l}\text { Kołodziejczyk 2015; Kowalczyk and Derek 2010; } \\
\text { Maziarz et al. } 2017\end{array}$ \\
\hline $\begin{array}{l}\text { Ownership of land and its accessibility to tourist } \\
\text { traffic (private areas, military areas etc.) }\end{array}$ & Potocki 2004; Vystoupil and Šauer 2012 \\
\hline Existing network of roads and paths & Kołodziejczyk 2015; Kowalczyk and Derek 2010 \\
\hline $\begin{array}{l}\text { Distribution and density of the settlement } \\
\text { network }\end{array}$ & Kowalczyk and Derek 2010 \\
\hline Transport accessibility of the area & $\begin{array}{l}\text { Guldan 2006; Kołodziejczyk 2015, 2019; } \\
\quad \text { Maziarz et al. } 2017\end{array}$ \\
\hline $\begin{array}{l}\text { Popularity of individual areas and } \\
\text { attractions among tourists, } \\
\text { main directions of tourist movement }\end{array}$ & Kołodziejczyk 2015 \\
\hline $\begin{array}{l}\text { History of tourism development and the } \\
\text { predominant model of active tourism }\end{array}$ & $\begin{array}{l}\text { Kołodziejczyk 2019; Mazurski 2012; } \\
\text { Potocki 2004, } 2013\end{array}$ \\
\hline Devastation of paths and the adjoining land & $\begin{array}{l}\text { Bayfield 1973; Buchwał and Fidelus 2008; } \\
\text { Cole 1991, 1995; Cole and Bayfield 1993; Cole } \\
\text { and Trull 1992; Dale and Weaver 1974; Fidelus } \\
\text { 2008, 2010, 2014; Maziarz et al. 2017; Mika } \\
\text { 2003; Roovers et al. 2004; } \\
\text { Taczanowska et al. } 2014\end{array}$ \\
\hline Political factors & $\begin{array}{l}\text { Briedenhann and Wickens 2004; } \\
\text { Potocki 2004, 2010, } 2013\end{array}$ \\
\hline $\begin{array}{l}\text { Openness of state borders (in the case of trails } \\
\text { running in the border zone) }\end{array}$ & Kołodziejczyk 2014a, 2019 \\
\hline Need to provide security to tourists & Lijewski et al. 2002 \\
\hline
\end{tabular}

connected by the nature of the landscape - all were created in Late Cretaceous sandstones, which as a consequence of erosion took the form of so-called rock cities or ruiniform relief (Migoń et al. 2017, 2018; see also: Adamovič et al. 2006; Cílek and Kopecký 1998). All three localities are concerned crucial examples of geoheritage in Central Europe.

\section{Aims and Methods}

The aim of the article is to determine the transformations of the networks of hiking trails within the boundaries of selected protected areas in the period of political transformation in Poland and the Czech Republic. Three areas were selected for the research (Fig. 1): (1) Prachov Rocks Nature Reserve (Czech Prírodní rezervace Prachovské skály) with adjacent fragments of the Bohemian Paradise Protected Landscape Area (Czech Chráněná krajinná oblast Český ráj) in the Czech Republic, (2) Adršpach-Teplice Rocks National Nature Reserve (Czech Národní přrodní rezervace Adšpašsko-teplické skály) in the Czech Republic, (3) Table Mountains National Park (Polish Park Narodowy Gór Stołowych) in Poland. They represent highly attractive sandstone landscapes (Cílek and Kopecký 1998; Härtel et al. 2007), which are one of the most important geotourist destinations in both countries. The author wants to see if and how the social, political and economic changes taking place in Central Europe at that time influenced the network of hiking routes. Analysis covers the entire period from the end of communism (1980s) up to present days to capture long-term processes. In addition, changes in the field of tourism infrastructure and ways of interpreting geoheritage are taken into account. Tourist trails are tightly connected with the latter problem, as they make the individual fragments of rock cities available. They can lead tourists to the right points of observation and without them the promotion of geoheritage would be much more difficult. The key element, however, is the transfer of geological knowledge, which is also partly the subject of analysis in this work. Educational paths concerning geology and relief, information and didactic panels focused on similar topics, signposts, museums and expositions as well as offer of guided tours were taken into account.

For the analysis of the networks of hiking trails chosen elements of the graph theory were used, especially coefficients connected with topologic analysis of spatial structure. It was assumed that every junction of tourist trails is a node of an undirected planar graph and the course of trail between junctions is a section of a graph. A situation when few trails lead along one path is also analysed as a singular section. In reference to works by Kołodziejczyk (2014a, 2015, 2018, 2019), Krakowiak (1997), Styperek (2001, 2002) and Taczanowska et al. $(2014,2017)$ in the analysis, several coefficients were 
Fig. 1 Location of study areas. a Prachov Rocks Nature Reserve. b Adršpach-Teplice Rocks National Nature Reserve.

c Table Mountains National Park

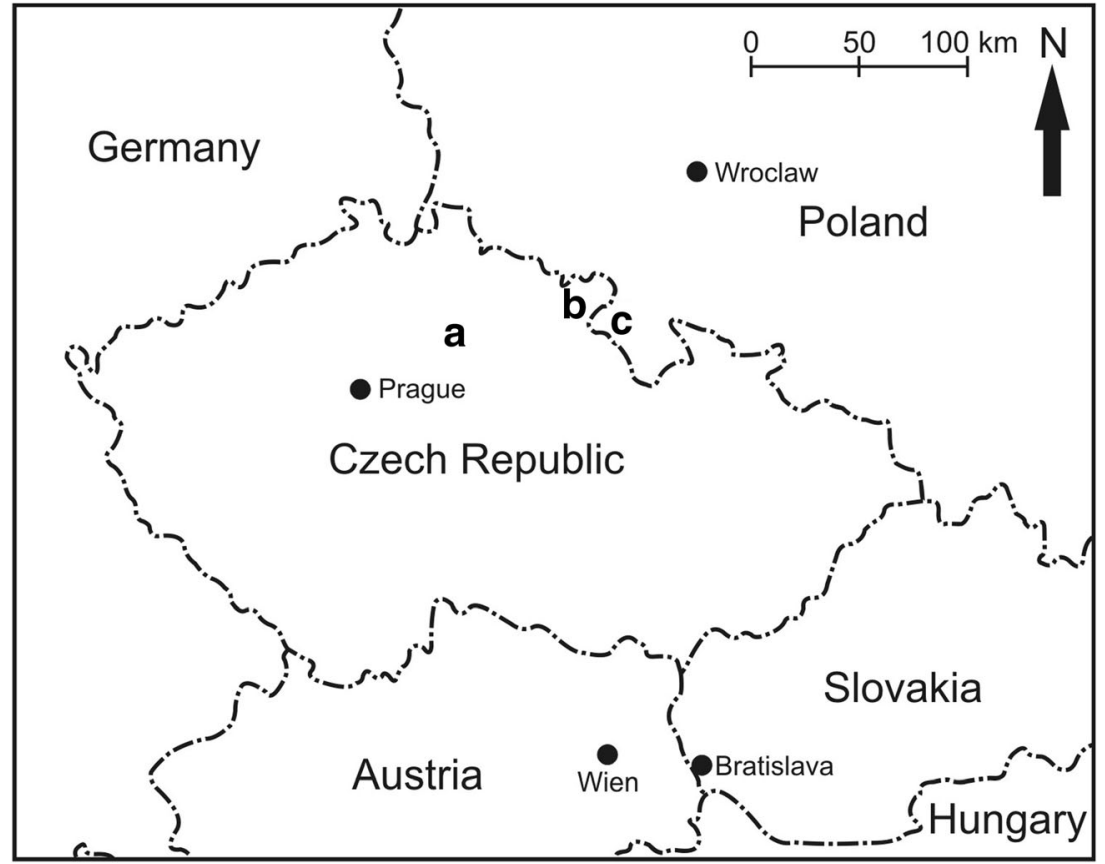

used (Taafee and Gauthier 1973; Potrykowski and Taylor 1982; compare: Gross et al. 2018):

- $\alpha$ coefficient: $\alpha=\mu /(2 v-5)$, where $\mu$ is the cyclomatic number counted from the formula $\mu=e-v+p$, where $p$ is the number of isolated subgraphs,

- Kansky $\beta$ coefficient: $\beta=e / v$, where $e$-number of sections, $v$-number of nodes (the higher the $\beta$ coefficient is, the higher is the coherence of the network),

- Kansky $\gamma$ coefficient: $\gamma=e /[3(v-2)]$ - this is a proportion of the existing number of sections to the maximal potentially existing number resulting from the number of existing nodes; results are between 0 (absolute lack of coherence) and 1 (all potential sections exist).

The analysis of a system of trails as a graph allows its simplification and, as a consequence, it is easier to distinguish areas with more or less dense network (reduction of the role of dandiness of paths, problematic when using a regular map) and the number of possible connections. At the same time, above-mentioned coefficients not only help to assess the level of development and coherence of the network, but also enable comparison of various systems or the same system in following years, what is the main aim of this paper. Moreover, the values of indicators $\alpha$ and $\gamma$ allow to qualify a given network of trails to one of the network shape types according to the classification developed by Taafee and Gauthier (1973), modified by Styperek (2001): the least developed and consistent core system (only the main route with accession paths, $1 / 3 \leq \gamma \leq 1 / 2 ; \alpha=0 ; v \geq 4)$, slightly more elaborate the corelattice $\operatorname{system}(1 / 3 \leq \gamma \leq 1 / 2 ; 0 \leq \alpha \leq 1 / 2 ; v \geq 4)$, then the lattice system $(1 / 2 \leq \gamma \leq 2 / 3 ; 0 \leq \alpha \leq 1 / 2 ; v \geq 4)$ and the delta system (the most consistent with virtually all possible inter-node connections, $2 / 3 \leq \gamma \leq 1 ; 1 / 2 \leq \alpha \leq 1 ; v \geq 3$ ). This classification helps to determine the shape of a network in a graphical way, but also gives some tips for the development of tourist infrastructure (Kołodziejczyk 2019).

Moreover, in terms of issues examined in the work, the most helpful methods were the analysis of maps and field studies focused on tourist infrastructure (including geoheritage interpretation) connected with trails. Archival maps from 1980s, 1990s and the beginning of the twentyfirst century were used, as well as updated tourist maps available in the internet (Table 2). For individual networks of trails and years analysed, the archival maps were sought representing the largest available scale (as accurate as possible). The process was conditioned by their availability. As a consequence, the maps have scales from 1:10,000 to $1: 160,000$, although those in the scale of $1: 25,000$ prevail. Analysed maps show all the hiking trails existing in a given period, which was verified on the basis of tourist guides for the 1980s and 1990s (including (Olympia 1982; Martynowski and Mazurski 1988; Pilous et al. 1982)) and field survey for modern times. The moment for which individual maps show best the condition of a network of hiking trails is usually given in the map's data sheet. In the case of absence of appropriate information, the year for which the map is up-to-date was identified on the basis of an analysis of scientific publications presenting the history of tourist infrastructure development in a given area (Dudziak and Potocki 1995; Kołodziejczyk 2014b; Mazurski 2012; Potocki 2004). Analyses for contemporary route networks were carried out on the basis of 
Table 2 Maps used for the analysis of networks of hiking trails in chosen protected areas

\begin{tabular}{|c|c|c|c|c|c|}
\hline Studied area & $\begin{array}{l}\text { Year for which the } \\
\text { network of trails } \\
\text { is analysed }\end{array}$ & $\begin{array}{l}\text { Release date } \\
\text { of the map }\end{array}$ & $\begin{array}{l}\text { Scale of the } \\
\text { map }\end{array}$ & Type of publisher & Reference \\
\hline \multirow{3}{*}{$\begin{array}{l}\text { Prachov Rocks } \\
\text { Nature Reserve }\end{array}$} & $1980 \mathrm{~s}$ & 1986 & $1: 10,000$ & National, civil & Kartografie 1986 \\
\hline & 1993 & 1993 & $1: 10,000$ & National, civil & Kartografie Praha 1993 \\
\hline & 2018 & Updated regularly & $\mathrm{n} / \mathrm{a}$ & $\begin{array}{l}\text { Private internet } \\
\text { provider Seznam.cz }\end{array}$ & Seznam.cz n.d. \\
\hline \multirow{5}{*}{$\begin{array}{l}\text { Adršpach-Teplice } \\
\text { Rocks National } \\
\text { Nature Reserve }\end{array}$} & 1974 & 1975 & $1: 25,000$ & National, civil & Kartografie 1975 \\
\hline & 1989 & 1991 & $1: 25,000$ & National, civil & Kartografie Praha 1991 \\
\hline & 1993 & 1993 & $1: 25,000$ & $\begin{array}{l}\text { National, military, in } \\
\text { cooperation with } \\
\text { a tourist society }\end{array}$ & Vojenský kartografický ústav 1993 \\
\hline & 2007 & 2007 & $1: 120,000$ & Private & ExpressMap 2007 \\
\hline & 2018 & Updated regularly & $\mathrm{n} / \mathrm{a}$ & $\begin{array}{l}\text { Private internet provider } \\
\text { Seznam.cz }\end{array}$ & Seznam.cz n.d. \\
\hline \multirow[t]{7}{*}{$\begin{array}{c}\text { Table Mountains } \\
\text { National Park }\end{array}$} & 1st half of $1980 \mathrm{~s}$ & 1985 & $1: 60,000$ & National, civil & $\begin{array}{l}\text { Państwowe Przedsiębiorstwo } \\
\text { Wydawnictw Kartograficznych } 1985\end{array}$ \\
\hline & 1988 & 1988 & $1: 160,000$ & National, civil & Martynowski and Mazurski 1988 \\
\hline & & 1991 & $1: 50,000$ & National, civil & Kartografie Praha 1991 \\
\hline & 2004 & 2008 & $1: 50,000$ & Private & SHOCart 2008 \\
\hline & 2007 & 2007 & $1: 30,000$ & Private & Plan 2007 \\
\hline & & 2007 & $1: 120,000$ & Private & ExpressMap 2007 \\
\hline & 2018 & Updated regularly & $\mathrm{n} / \mathrm{a}$ & Internet map & Mapa turystyczna n.d. \\
\hline
\end{tabular}

available modern paper maps and constantly updated online maps. In terms of studies focused on tourist infrastructure, its distribution within the network, size by reference to tourist traffic and technical state were investigated, however mostly facilities located directly near trails were taken into account (as trails are the only or predominant way to move around the area). Among them are accommodation and catering facilities, infrastructure of resting points (benches, tables, roofs, shelters) and forms of adaptation of sightseeing values for tourism purposes (i.e. stairs, footbridges or handrails in case of sections leading through rock formations, swamps or along streams), as well as facilities connected with geoheritage interpretation. Regarding the reasons for the changes, questions were asked to the authorities of individual protected areas, although not always comprehensive answers were obtained. In the correspondence, attention was paid both to the reasons for the liquidation of individual sections, as well as the opening of new ones.

\section{Tourism in Sandstone Landscapes}

Sandstone rocks-cities (isolated or their complexes) are a traditional subject of tourist interest, visited or portrayed by many important personalities (Humboldt, Goethe, emperors and kings of the Austro-Hungarian and Prussian empires, Caspar David Friedrich, John Quincy Adams etc.). This is usually due to their unusual shapes, as objects that stand out in the landscape often become attractors of tourism movement. In the case of Central Europe, it is the sandstone landscapes that belong to places where natural or active tourism began to develop at the earliest. In the Czech Republic (Vystoupil and Šauer 2012), in this context, it is enough to mention the so-called Kokořínsko-Máchův kraj country north-east of Prague (although the proximity of the capital has undoubtedly contributed to the popularity of the place), Bohemian Paradise or the impressive landscapes of Czech Switzerland with the largest natural rock arch in Europe, called Pravčická brána/Pravčice gate (Bruthans et al. 2014; Juda et al. 2012; Vařilová et al. 2013). In the present Polish lands first of all the Table Mountains in the Sudetes (Mazurski 2012) can be pointed out, but also the rock city near Ciężkowice or the nature reserve "Prządki" near Krosno in the Carpathian Foothills (Alexandrowicz 1970, 2006, 2008) are worth noticing. Initially, only the attractive shapes of rocks aroused interest, but in recent years - in the face of the dynamic development of geotourism (Hose 1995, 2005a, 2012; Migoń 2012a; Newsome and Dowling 2010) — they also become objects with various didactic functions in the field of geology, geomorphology and environmental transformations. Traditionally, the most popular are the rocks which are associated with legends or authentic historical events or which are the place of religious or folk celebrations. These traditions caused that selected rocks (sandstone, but also granite or of 
other types) became a permanent element of local or even national culture, they were perpetuated by painters and writers (Alexandrowicz 2008). Nowadays, however, such features become more and more important due to their role in learning about geoheritage (Migoń 2012a). Alexandrowicz (2008, p. 686; compare: Kubalíková 2018; Migoń 2016) indicates a number of aspects related to sandstone formations, which may become the subject of tourists' interest (although the author refers to sandstones in the Polish Carpathians, which are different than the sandstones in north-east Czech Republic and south-west Poland, the aspects presented below are more or less universal):

- "lithological types of sandstones and conglomerates, the differentiation of particle sizes and bedding, especially characteristic of the fluxoturbidites;

- specific landforms generated by geomorphological processes such as erosion, denudation, cryoplanation, weathering and mass movements;

- joint system and its role in the shaping of the rocky forms;

- diversity of the sedimentary structures exposed on the surfaces of rocky forms due to the selective weathering;

- forms and phenomena of the chemical and mechanical weathering;

- unique, scenic shapes of the rocky forms, as aesthetic elements of landscape;

- rocky forms as viewpoints;

- rocky forms as specific environments of rock flora and fauna assemblages;

- archaeological sites in the pseudo-karst caves;

- historical events and traditions connected with the rocky forms, as well as legends and folk ceremonies;

- rocky forms as specific scenery for film shooting and other open-air spectacles".

Currently, official tourist routes lead across most sandstone landscapes that are attractive from the tourist perspective or these areas are at least marked on tourist maps. Difficult access to some of the rocks or places from which one could observe them (e.g. due to steep slopes or landslides) is sometimes a problem. Until the beginning of twenty-first century in Central Europe, there was a lack of educational offer that would bring geoheritage and geodiversity closer to tourists (Alexandrowicz 2008). Unfortunately, this problem is still valid in Poland - the number of properly prepared and kept educational paths is still small, and these existing are much more often connected with the elements of the animated nature. There is also a lack of popular science publications on geology and relief referring to actual sites that can be visited by tourist. The situation in the Czech Republic is much better. There are now many interpretation tables placed in interesting locations, various educational paths were created. Besides classical interpretation panels, the QR-codes are frequently used giving links to more information or videos, including 3D animations (Rapprich et al. 2017a). In recent years, even means of augmented reality are being applied. It is also a good practice to create a national network of geotouristic objects, like geoparks (Alexandrowicz 2006; Słomka et al. 2006; Słomka and Doktor 2011). A crucial aim is to develop a complete tourism product based on geoheritage (Rogowski 2016).

\section{Study Areas}

The Bohemian Paradise Protected Landscape Area is considered one of the largest natural tourist attractions in the Czech Republic (David and Soukup 2004; Geodézie On Line 2011b; Marek 2013; Mertlík and Adamovič 2016). It is located in the northern part of the Czech Republic, at the foothills of the Sudetes, and protects part of the geomorphological unit known as the Czech plate (Czech Česká tabule (Czudek et al. 1972)), a plateau mainly made of cuboid sandstones (resulting from the form of their fracturing, creating cubes of sandstones), sedimented in the shallow Cretaceous sea (Mitchell et al. 2010; Uličný 2001; Uličný et al. 2009). Geologically, the area belongs to the Bohemian Cretaceous Basin, which occupies the central and northern part of the Bohemian Massif. Stratigraphy includes rock series from the Cenomanian to the Coniacian (Migoń and Pijet-Migoń 2006; Uličný 2001; Uličný et al. 2009). The relief was also influenced by Neogene volcanism, which is reflected today in locally present necks and lava covers (Petronis et al. 2015, 2018; Rapprich et al. 2007, 2017b). Currently, the entire Bohemian Paradise has been recognised not only as a protected landscape area (what happened already in 1955), but also-in 2005 as the first such area in the Czech Republic - as a geopark, being now a member of national, European and global geopark networks (Kubalíková 2018; Migoń and Pijet-Migoń 2006). The Bohemian Paradise Protected Landscape Area consists of three isolated parts and within the smallest, southern section the Prachov Rocks Nature Reserve (Fig. 2) is located. It is the most famous rock city in cuboid sandstones of the Czech plate.

The Adršpach-Teplice Rocks (Fig. 3) belong to the most extensive rock massifs in the Czech Republic and Central Europe (Královéhradecký kraj 2015). They are part of the Broumov Highland (Geodézie On Line 2011a), which is a lowering of the terrain between higher: Giant Mountains in the north-west, the Kamienne and Sowie mountains in the north-east and the Orlickie/Orlické Mountains in the southeast. In terms of geology, it is part of the Mid-Sudetes Basin which was the bottom of a sea in the Cretaceous (Vítek 2016). Local sandstones are formed of flint grains with the admixture of feldspar (Nováková and Poulíčková 2004). Together with the neighbouring: Mt Krrižový vrch Nature Reserve and Mt Lysý vrch Nature Monument, the Adršpach-Teplice Rocks 
Fig. 2 Sections of hiking trails in the Prachov Rocks Nature Reserve. a View of the Emperor's Avenue (Czech Císařská chodba) with intersection of few hiking trails. b Mouse Hole (Czech Myš dira), a narrow passage with minimum width of $60 \mathrm{~cm}$
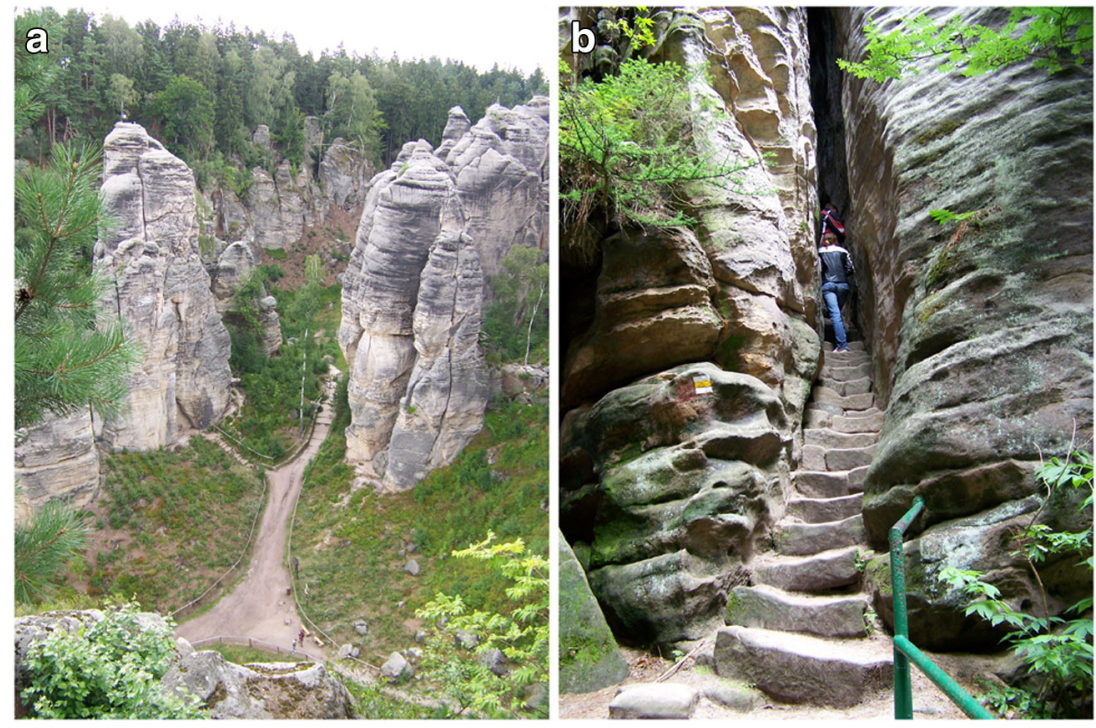

form a vast area of sandstone formations, having elliptical shape, spread along the arch of the local railway line from Teplice nad Metují through Adršpach, Janovice to Trutnov. Traditionally, the complex with an area of about $20 \mathrm{~km}^{2}$ is divided into two parts - the Adršpach Rocks in the northwest and the Teplice Rocks in the south-east (Kartografie Praha 1991).

Finally, the Table Mountains (Polish Góry Stołowe; Fig. 4) are a mountain range in the central part of the Sudetes, which themselves create a north-eastern rim of the Bohemian Massif. The mentioned name refers to Polish section of the range, whereas the Czech continuation is called the Broumov Highland. The Table Mountains are famous for the "presence of nearly flat-lying sandstone beds of
Cretaceous age at relatively high elevation" ((Migoń 2012 b), p. 6). The morphology of the area is of tableland type, with several levels being better or worse pronounced. The typical landscape features are vast planar surfaces and sandstone mesas separated by steep escarpments, up to $300 \mathrm{~m}$ high (above the town of Radków, Fig. 11) and crowned with sandstone precipices, which are the most impressive and attractive parts of the area due to many viewpoints and dynamic relief. The sequence of steep slopes and flat terrain is repeated at various altitudes, reaching $919 \mathrm{~m}$ a.s.l. in the highest point (Mt Szczeliniec Wielki). Main attractions of the Table Mountains from the geotourism point of view are (Fig. 11) the rock city on the top of $\mathrm{Mt}$
Fig. 3 Fragments of the main tourist routes in both rock cities in the Adršpach-Teplice Rocks National Nature Reserve. a Teplice Rocks (passage through Sibír). b Adršpach Rocks (trail in the Old Parts)
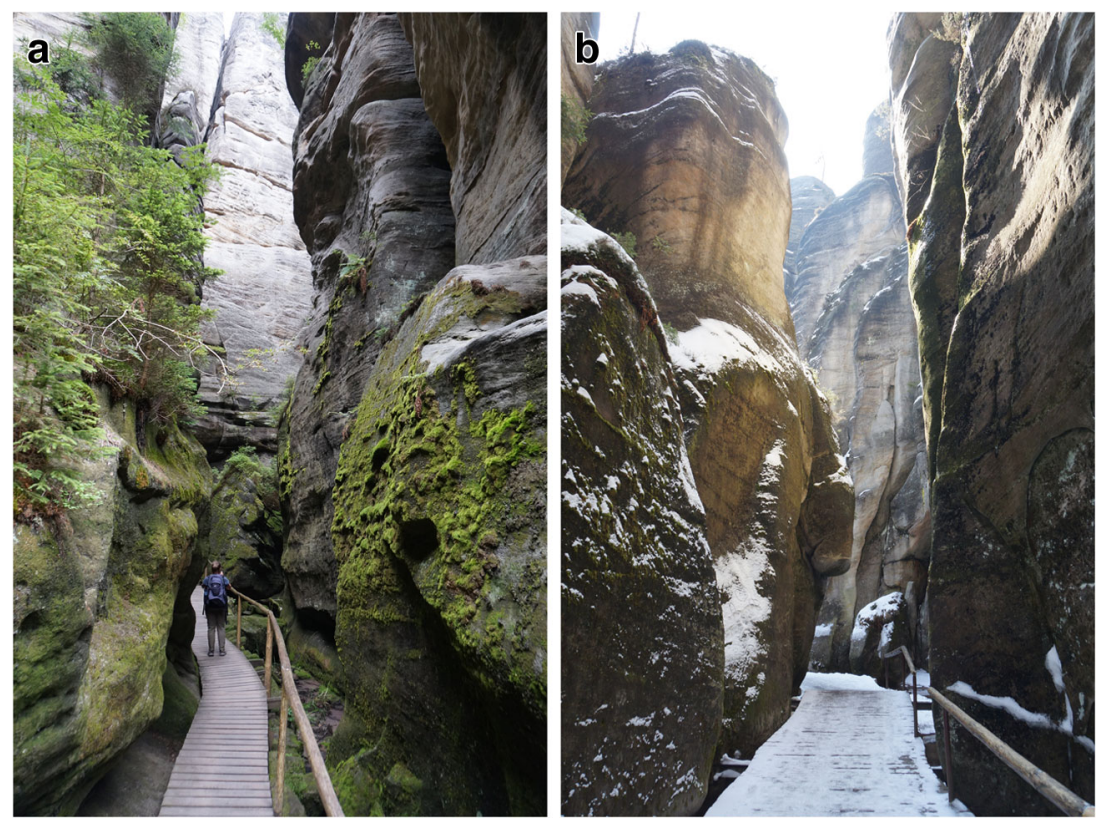
Fig. 4 Selected rock cities of the Table Mountains National Park. a Mt Szczeliniec Wielki-view from the highest point (919 $\mathrm{m}$ a.s.1.) situated on the top of a rock formation called Fotel Pradziada (Ancestor Armchair). b Tourist trail between Białe Skały (White Rocks)
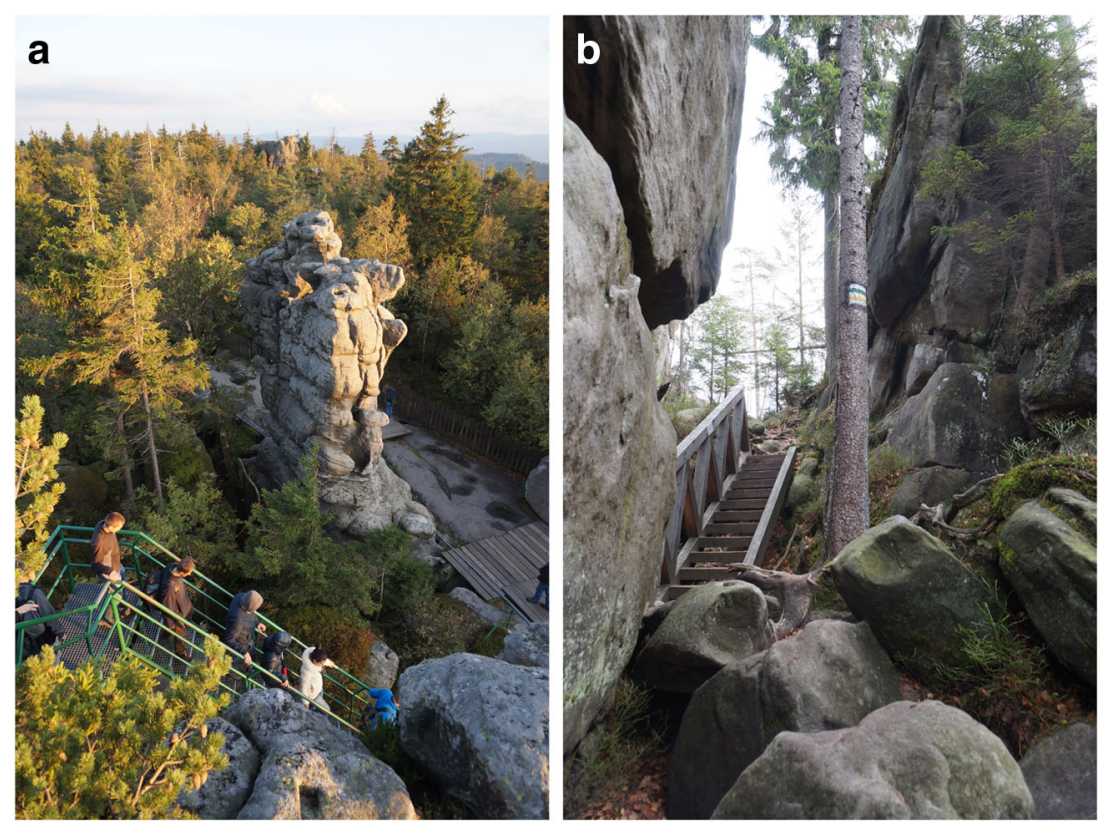

Szczeliniec Wielki mesa (Fig. 4a) and the maze of Błędne Skały (Errant Rocks).

A comparison of main characteristics of analysed protected areas was presented in Table 3, while below is an outline of the history of tourism development in these places, important from the perspective of this paper objectives. The beginnings of tourism in the Bohemian Paradise date back to the 1st half of the nineteenth century, when excursions to the most famous Prachov Rocks were organised by junior high school (gymnasium) professors from nearby Jičín. In 1804 or

Table 3 Comparison of protected areas analysed in the paper

\begin{tabular}{|c|c|c|c|}
\hline Characteristic & $\begin{array}{l}\text { Prachov Rocks } \\
\text { Nature Reserve }\end{array}$ & $\begin{array}{l}\text { Adršpach-Teplice Rocks } \\
\text { National Nature Reserve }\end{array}$ & $\begin{array}{l}\text { Table Mountains } \\
\text { National Park }\end{array}$ \\
\hline $\begin{array}{l}\text { Date of establishment of } \\
\text { the protected area }\end{array}$ & 1933 & 1933 & $\begin{array}{l}\text { 1993, earlier landscape park (est. 1981), } \\
\text { earlier several nature reserves (from } \\
\text { late 1930s) }\end{array}$ \\
\hline Area & $261.91 \mathrm{ha}$ & $1803.43 \mathrm{ha}$ & 6347.71 ha \\
\hline Altitude & $350-450 \mathrm{~m}$ a.s.l. & 509-786 m a.s.l. & 400-919 m a.s.l. \\
\hline Major landscape forms & $\begin{array}{l}\text { Several assemblages of sandstone } \\
\text { walls and towers, separated by deep } \\
\text { clefts and avenues }\end{array}$ & $\begin{array}{l}\text { Sandstone plateaus covered with rocks; } \\
\text { ridges; Adršpach Rocks - isolated } \\
\text { towers and rock bastions; Teplice } \\
\text { Rocks - long and often overhanging } \\
\text { rock walls }\end{array}$ & $\begin{array}{l}\text { Vast planar surfaces and } \\
\text { sandstone mesas separated } \\
\text { by steep escarpments, up to } \\
300 \mathrm{~m} \text { high; amphitheatres }\end{array}$ \\
\hline $\begin{array}{l}\text { Minor landscape } \\
\text { forms and other } \\
\text { geoheritage attractions }\end{array}$ & $\begin{array}{l}\text { Labyrinth of walls and narrow passages; } \\
\text { caves of the rubble type; } \\
\text { pseudo-karst microforms (honey- } \\
\text { comb weathering) }\end{array}$ & $\begin{array}{l}\text { Maze of gorges and rock towers; } \\
\text { specific microclimate in deep and } \\
\text { shady ravines }\end{array}$ & $\begin{array}{l}\text { Rock labyrinths (ruiniform relief); } \\
\text { hoodoo (mushroom) rocks; block } \\
\text { fields (on major escarpments); iso- } \\
\text { lated sandstone boulders (relicts of a } \\
\text { long gone sandstone slab) }\end{array}$ \\
\hline Major cultural attractions & $\begin{array}{l}\text { Evidence of an early Bronze age } \\
\text { settlement on a plateau called Starý } \\
\text { Hrádek; remains of fortifications } \\
\text { (prehistoric Prachov fortified site, } \\
\text { medieval Pařez castle); } \\
\text { commemorations associated with the } \\
\text { Prussian-Austrian war of } 1866\end{array}$ & $\begin{array}{l}\text { Relics of three medieval castles built on } \\
\text { the rocks (Adršpach royal castle, } \\
\text { Skály castle, Strrmen castle) }\end{array}$ & $\begin{array}{l}\text { Relicts of forts from the eighteenth } \\
\text { century; more cultural attractions in } \\
\text { the vicinity, e.g. the pilgrimage centre } \\
\text { of Wambierzyce, paper mill in } \\
\text { Duszniki-Zdrój, Chapel of Sculls in } \\
\text { Kudowa-Czermna, open-air museum } \\
\text { in Kudowa-Pstrążna }\end{array}$ \\
\hline Selected literature & $\begin{array}{l}\text { Adamovič et al. 2006; Balatka and } \\
\text { Sládek 1984; Migoń and Pijet-Migoń } \\
\text { 2006; Škvor 1982; Vítek } 1980\end{array}$ & $\begin{array}{l}\text { Gutzerová and Herben 1998; Marková } \\
\text { 2013; Nováková and Pouličková } \\
\text { 2004; Vítek } 2016\end{array}$ & $\begin{array}{l}\text { Martynowski and Mazurski 1988; } \\
\text { Migoń 2012b, 2012c, 2012d, 2012e; } \\
\text { Wojewoda 2008, 2012 }\end{array}$ \\
\hline
\end{tabular}


1813, the rocks were probably visited by the Austrian Emperor Francis I (1768-1835), what is commemorated by the name of the Emperor's Avenue (Czech Císařská chodba; Fig. 2a) attributed to one of the rocky passages seen by the ruler. The beginning of the organised tourism in this area is considered 1879, when Vojta Naprstek (1826-1894), an explorer, ethnologist, businessman and a promoter of the Bohemian Paradise, prepared a trip from Prague to Jičín and the nearby rock labyrinth. It was the employees and students of the Jičín grammar school who had the greatest merit in making the Prachov Rocks accessible, in particular its director František Lepař (1831-1899), who became the chairman of the Jičín branch of the Club of Czech Tourists and obtained the permission for all works from the owner of this area, count Ervín Schlik (1852-1906) (Kartografie Praha 1993). The Club of Czech Tourists was responsible for building tourist routes in the rocks, being especially active after the Czechoslovakian state came into existence. Besides, the Schlik family until the 1 st half of the twentieth century actively supported the development of tourism in this part of the Bohemian Paradise. During the Second World War, all properties of the Schlik family were forcefully transferred to administration of the German Nazi. After 1948, the area was nationalised and the Prachov Rocks were managed by the Jičín Municipal National Committee. This is the period when mass tourism was typical for the rock city. Restitution in 1996 saw historical property transferred back to the former owners. In 2000, the Schlik family started to manage the tourist area of the Prachov Rocks in cooperation with administrators from the Bohemian Paradise Protected Landscape Area (Schlik n.d.). Although being a nature reserve, the Prachov Rocks are nowadays very popular among tourists, especially as they are located in the half way from Prague to the Giant Mountains, also being very frequented. A dense network of hiking trails (Fig. 6) enables various trips, also in winter, as the area is open to the public all year round. However, this is the only nature reserve within the Bohemian Paradise Protected Landscape Area where hiking beyond official routes is prohibited and fined. It is a consequence of many acts of vandalism in 1970s and 1980s.

The Adršpach-Teplice Rocks were partially known already in the Middle Ages, when they served as places of concealment of the local population during wars. They played a similar role during the Counter-Reformation. The Czech brothers, persecuted after the fall of the Czech uprising in 1620 and the defeat of the Czech army on Mt Bílá hora, celebrated their secret services here. In 1790, the rock city was visited by Johann Wolfgang Goethe (Baumgart 1940; Chmal 2010; Mazurski 2012; Ziolko 1992). However, the attractiveness of the rock cities was discovered only after the great fire of 1824, when the entire forest covering the area was destroyed (Kartografie Praha 1991). Exposed fanciful rock forms attracted people who penetrated previously unknown central parts of rock cities. In the case of the Teplice Rocks, the so-called Old Parts (being a continuation of a previously known route from the east along the Skalní potok-Rock Stream) were made available after the fire in 1824. Route from the south-west was built in 1846 , and the extremely spectacular passage through the narrow gorges of Anenské údolí and Sibír (Fig. 3a) was opened not until 1868 (Kartografie Praha 1991). The so-called Old and New Parts are distinguished also in the Adršpach Rocks (Fig. 3b). In all cases, it was necessary to build paths, remove or even forge boulders, and in the narrowest ravines used by streams - construct bridges. The process was connected with significant transformations of the environment. Nowadays, the main problem from the perspective of the interpretation of geoheritage is the overgrowing of rock cities, especially the Teplice part, where the valleys are wider. Many rock formations, which were visible tens or so years ago and have their names marked on maps, are now obscured by tall trees.

Due to difficult accessibility and coverage of forests, penetration of the Table Mountains began clearly later than the neighbouring regions. Spas located south from the area (Kudowa-Zdrój, formerly Bad Kudowa, and Polanica-Zdrój, formerly Bad Altheide) have been known since at least the seventeenth century (Mazurski 2012). The first tourist visits to the Table Mountains date back to the end of the eighteenth century and are related to the military activities in this area, which was at the time the border between Austria and Prussia (established in 1742). Convenient locations for the construction of forts and fortresses were sought after. The choice fell on the sandstone plateaus, which had to be examined first. The first place that became the target of tourist movement was the highest peak of the Table Mountains, Mt. Szczeliniec Wielki, more precisely the impressive rock city covering this sandstone plateau. It was soon made accessible by providing steps (mostly hewn in sandstone) and bridges over rock clefts. They were built for 23 years mainly by Franz Pabel (1773-1861) (Martynowski and Mazurski 1988), a local forester from Karłów (then Carlberg), who in 1813 received the official licence of a guide from the Prussian emperor Friedrich Wilhelm III (probably the first distinction of this kind in Europe). The Mt. Szczeliniec Wielki was visited by Johann Wolfgang Goethe and king of Prussia Friedrich Wilhelm II (1744-1797) in 1790, John Quincy Adams (1767-1848, American ambassador, later the President of the USA) in 1800, and by Friedrich Wilhelm III (1770 1840 ) in 1813. In 1845, the tourist lodge on the northern edge of the Szczeliniec Wielki mesa was built (Adams 2016; Mazurski 2012; Migoń 2012e). It is used until today, being the only tourist lodge in the Polish Sudetes with no access by car (Fig. 5). In the second half of the nineteenth century, a local tourist organisation, Glätzer Gebirgsverein (GGV), marked various hiking trails and created many viewpoints 


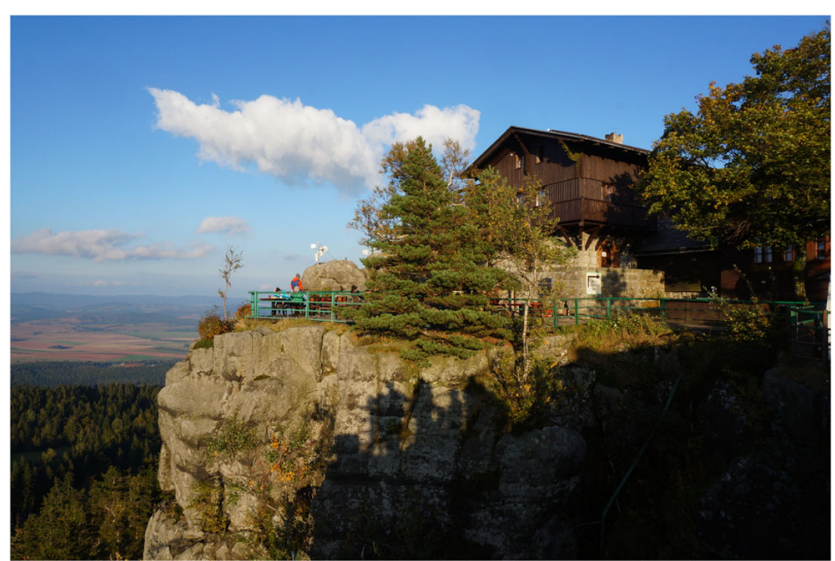

Fig. 5 Tourist lodge on Mt Szczeliniec Wielki

in other parts of the Table Mountains (Potocki 2004), introducing many artificial modifications of the natural environment. For example in the Pośna valley on the northern escarpment artificial cascades and waterworks were created along a tourist trail. The establishment of large-scale protected areas in 1980s and 1990s (landscape park, later national park) contributed to the increase in the popularity of the Table Mountains, especially areas outside the previously existing reserves. Mt. Szczeliniec Wielki and the Błędne Skaty Rocks were the only highly frequented places in this region throughout the twentieth century, while the southern and eastern parts of the area were not highly frequented, which resulted from difficult access and poorly developed network of tourist trails. Today the Table Mountains are one of the most popular tourist regions in south-west Poland with approximately 300,000 visitors a year (Migoń 2012e).

\section{Results}

\section{Prachov Rocks Nature Reserve}

The network of hiking trails in the Prachov Rocks is part of the network of routes in the south-eastern section of the Bohemian Paradise Protected Landscape Area (Fig. 6). However, we can clearly see the difference in the density of the network in favour of the nature reserve analysed here, which corresponds with its obviously greater popularity among tourists. Trails in adjacent areas are primarily intended to lead to the Prachov Rocks from neighbouring towns (Jičín, Sobotka, Mladějov, Libuň, Železnice, Valdice), providing access from numerous accommodation facilities and public transport stops around the area (but still, there are parking lots at both main gates to the rocks). This arrangement is thought to be a stimulus not to use a car when visiting the reserve. Within the limits of the Prachov Rocks Nature Reserve, the density of hiking trails is slightly varied. It is the highest in the central and eastern parts, what corresponds with the occurrence of the most spectacular, highest rock walls (Migoń and Pijet-Migoń 2006). In the other parts, the number of impressive rocks is smaller; hence, tourists are less interested in them, or the human presence was deliberately limited (north of the reserve, mainly the Starý hrádek region with significant archaeological findings and valuable flora and avifauna). On several rock towers view platforms were constructed. Short side-trails lead to most of them, usually being not longer than tens of metres. Marking of trails in the central part of the reserve was designed to create two circular routes connecting all the more significant viewpoints. The green trail is about $3.4 \mathrm{~km}$ long and it takes $2 \mathrm{~h}$ to walk it (the time is quite long due to elevations and narrow passages). The shorter route is marked yellow, it is $1.8 \mathrm{~km}$ long and $1 \mathrm{~h}$ is needed to cover it. Possibly the most impressive path leads through the Emperor's Avenue where rock walls are up to $40-50 \mathrm{~m}$ high (Fig. 2a).

Comparing the network of routes in 1980s, 1993 and 2018 (Fig. 6), it can be seen that there were no significant changes. According to maps showing situation in 1980s and 1993, the networks were identical. Until 2018, only two sections have been liquidated, and the change of course - but only in short fragments - included two other sections of trails - in the area of the U Peliška swimming place and the Skalní město (Rock City) hotel. The liquidation of the fragments of the routes resulted from the needs of nature protection and at the same time limited the possibility of penetrating the south-eastern part of the reserve. The course changes were purely technical and resulted from changes in accessibility of individual areas (mainly near the mentioned hotel). A small scope of changes should be explained primarily by the impressive popularity of the reserve and the fact that the local network of trails was formed many years ago (in most cases before the Second World War), so any elimination of longer sections would surely meet with dissatisfaction among tourists. On the other hand, no new routes have been created, as this is contrary to the rules of access to protected area, as well as technically difficult in the local rocky landscape. The key point is that the Schlik family decided to maintain the current way of using the land, i.e. the key role of active tourism. It brings significant income from admission fees and functioning of tourist infrastructure. Even the location of the cash desks, which are situated at two entrances to the main route in the reserve (from the tourist lodge in the west and the village of Prachov in the east), remained unchanged from the communist times. When it comes to changing the nature of tourism from mass to individual, it is mainly reflected in the way tourists arrive at the analysed area. Based on reports from the 1970s and 1980s, it is known that organised tour buses dominated (Schlik n.d.). Currently, most people arrive by cars, which causes problems with parking spaces (despite the increase in the area of parking lots). The offer of regular buses has also been expanded, which in the summer season run between the main attractions 


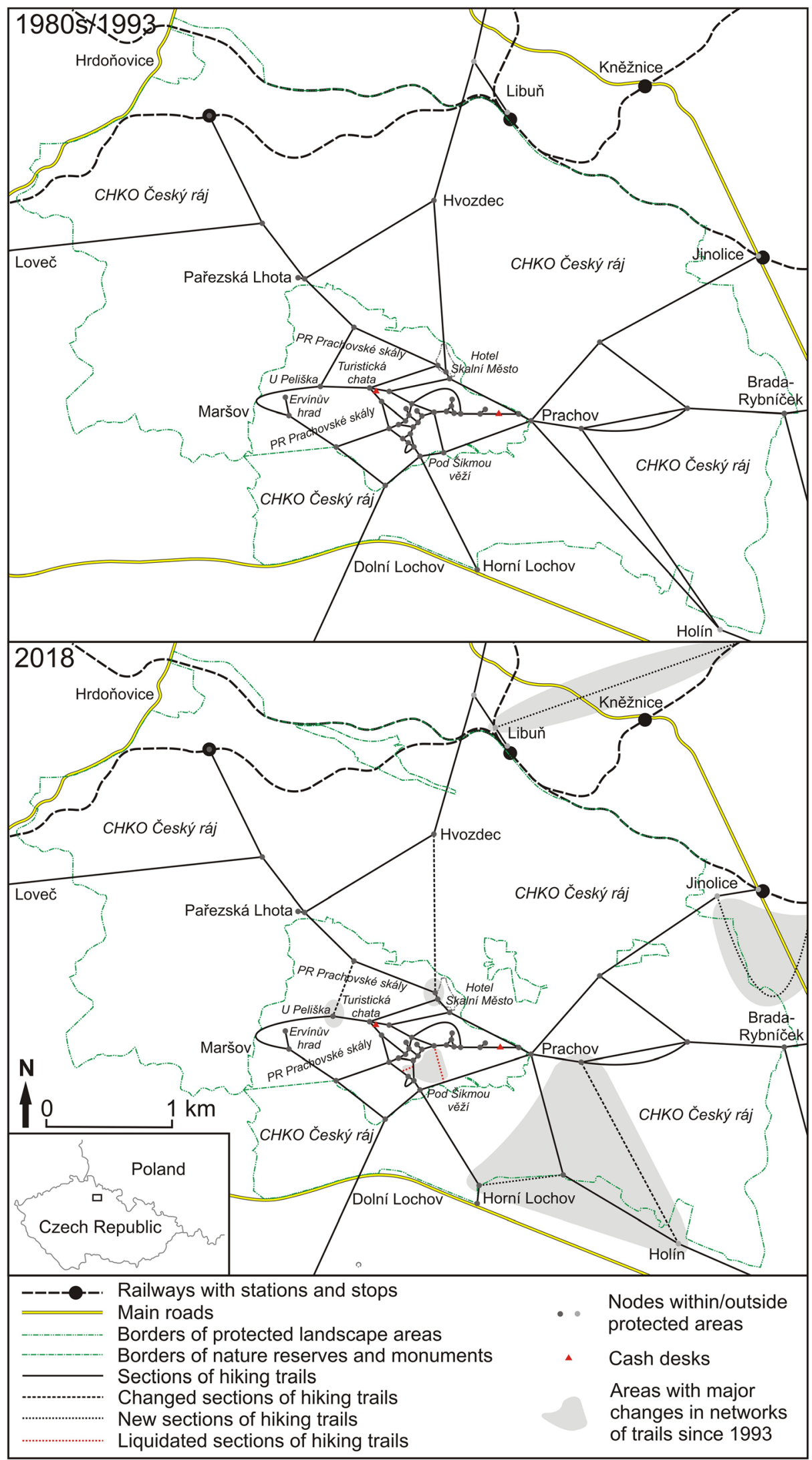

Fig. 6 Networks of hiking trails in the Prachov Rocks Nature Reserve and the surrounding parts of the Bohemian Paradise Protected Landscape Area in 1980s, 1993 and 2018. Note: the network of trails in 1980s and
1993 was identical. Based on: (Kartografie 1986; Kartografie Praha 1993; Seznam.cz n.d.) 
Table 4 Coefficients characterising networks of hiking trails in the Prachov Rocks Nature Reserve and the surrounding parts of the Bohemian Paradise Protected Landscape Area in 1980s, 1993 and 2018

\begin{tabular}{lll}
\hline Coefficient & \multicolumn{1}{l}{ Year } \\
\cline { 2 - 3 } & $1980 \mathrm{~s} / 1993$ & 2018 \\
\hline Total length (in km) & 38.9 & 39.7 \\
$\begin{array}{l}\text { Length within the nature reserve } \\
\quad \text { only (in km) }\end{array}$ & 15.9 & 15.6 \\
$\begin{array}{l}\text { Density of trails within the nature } \\
\left.\text { reserve only (km/km }{ }^{2}\right)\end{array}$ & 6.07 & 5.96 \\
Number of nodes & 48 & 47 \\
Number of sections & 74 & 73 \\
Kansky $\beta$ coefficient & 1.54 & 1.55 \\
Kansky $\gamma$ coefficient & 0.54 & 0.54 \\
$\mu$ cyclomatic number & 26 & 26 \\
$\alpha$ coefficient & 0.29 & 0.29 \\
\hline
\end{tabular}

Note: the network of trails in 1980s and 1993 was identical

of the whole Bohemian Paradise region (Kołodziejczyk 2014b). However, the tourist traffic remained very large and these changes did not have a direct impact on the network of hiking trails nor other forms of tourist infrastructure.

Small changes have also occurred in the network of trails stretching across protected areas surrounding the analysed reserve, i.e. the south-eastern part of the Bohemian Paradise Protected Landscape Area (Fig. 6). In addition to changes of the route of one of the trails leading from Prachov towards Jičín (resulting from ownership changes and the disappearance of one of the paths near the village of Holín), two new sections of trails were added, what is related to the creation of an educational path dedicated to the events of the PrussianAustrian war of 1866. Major changes in the trails network could not have been justified neither by a change in the intensity of tourist traffic nor by the nature protection reasons. However, new trails were introduced in the vicinity of the Bohemian Paradise Protected Landscape Area, linking it with other tourist regions. The existing marked routes connect the old (campsites, hotels) and the new (guesthouses, B\&B, rooms for rent) accommodation facilities with the Prachov Rocks Nature Reserve to a sufficient extent. There is a tourist trail leading through every village that performs tourist functions. Trails in the protected landscape area are much less frequented than in the nature reserve itself, so there is no reason for introducing new routes, especially that the existing networks seem fully effective.

The length of the network of hiking trails in the Prachov Rocks Nature Reserve and surrounding areas of the Bohemian Paradise Protected Landscape Area in 2018 increased slightly compared to 1993 (Table 4). This results from the liquidation of only two short sections of trails in the reserve and, at the same time, introduction of two longer sections in the peripheral zone of the protected landscape area with minimal changes to other routes. As a consequence, the length of trails within the nature reserve only decreased from 15.9 to $15.6 \mathrm{~km}$, similar to their density (change from 6.07 to $5.96 \mathrm{~km} / \mathrm{km}^{2}$ ), but in the whole analysed area, including the surrounding parts of the protected landscape, the length increased from 38.9 to $39.7 \mathrm{~km}$. Due to only minor changes in the network within the natural reserve, the graph coefficients were calculated for the wider area, including also the south-eastern part of the Bohemian Paradise Protected Landscape Area, which surrounds the reserve (Table 4). The number of nodes and sections of routes between them and, as a consequence, values of network cohesion indicators have almost not changed. Taking into account their values and classification developed by Taafee and Gauthier (1973), modified by Styperek (2001), the network of trails in the analysed area should be classified as the fairly well-developed lattice system, although the values of the $\gamma$ coefficient are close to being typical for the core system. This situation seems not entirely desirable in the case of a nature reserve, where the presence of tourists should be somewhat limited. This is confirmed by the very high density of the network of trails, amounting to about $6 \mathrm{~km}$ per sq. $\mathrm{km}$. Trails within the boundaries of the reserve only should be included to the lattice system, but the shape of the network is close to the most developed and consistent delta system. However, as mentioned above, due to the high tourist traffic and long tradition of wandering in this area, the liquidation of routes may be negatively perceived by the public opinion and may cause illegal dispersion outside the marked trails, which may have more serious negative consequences.

The first examples of advanced infrastructure focused on mass tourism in the Prachov Rocks occurred at the turn of the nineteenth and twentieth centuries. In the central part of the rock labyrinth since 1886, a wooden restaurant was functioning, built by the owner of the area, count Ervín Schlik. After 34 years, it was demolished and in its place in 1924 a big mountain lodge was built (Prachovské skály..., 1993). It was further enlarged in the 1930s into its modern look (Schlik n.d.). In 1901, hotel Pod Šikmou Věží was opened south from the rock labyrinth, being the oldest accommodation base in the area. In 1912, the Club of Czech Tourists bought a hotel in Horní Lochov and transformed it into a base for summer visits to the Prachov Rocks. More facilities were built in the 1930s, e.g. in 1935 the Skalní město hotel in the north-east (outside borders of the newly introduced nature reserve) and an organised swimming place (U Pelíška) in the central part of the protected area (it was still functioning at the beginning of 1990s (Kartografie Praha 1993)). Further development of infrastructure for mass tourism took place at the end of the 1950s and in the 1960s. At the time, a large recreational complex with camping sites, camping houses and a swimming pool was created by the ponds stretching to the north-east of the reserve (part of the so-called Jinolice ponds). Camping 
houses were also built near two (out of three) hotels surrounding the rock city, as well as near the Pařez pound in the northwest. Together with second homes (see (Fialová and Vágner 2001)) in the area within $2 \mathrm{~km}$ from the boundaries of the reserve, an exceptionally extensive accommodation base was created, usually combined with gastronomy.

Almost all above-mentioned facilities are still in use and in recent years new hotels, guesthouses and restaurants were created (David and Soukup 2004), as an answer to the development of individual tourism. The largest grouping of accommodation facilities in the area of the Prachov Rocks Natural Reserve is still the campsite complex surrounding the Jinolice ponds. The distance from them to the eastern entrance to the reserve is less than $1 \mathrm{~km}$. Both points in summer season are also connected by a regular bus line. Currently, two hotels (hotel Pod Šikmou Věží and Parkhotel Skalní město) are directly adjacent to the boundaries of the reserve, while several other facilities are located closer than $100 \mathrm{~m}$ from the protected area. The introduction of the free market economy resulted in the development of gastronomy and souvenir shops. During the communist period in the Prachov Rocks region, only a few dining options were available. Currently, in the neighbouring villages (Prachov, Jinolice, Březka), a lot of different types of restaurants and bars were opened, mostly seasonal ones. Together, this results in a very strong pressure on the reserve. Considering the size of tourist traffic, in the Prachov Rocks, there are very few rest areas for hikers (benches, tables, shelters, etc.). The shortage of this type of equipment results in tourists walking down from trails and resting on rocks or grass. Tourist and sightseeing information can be obtained at two tourist information centres (in the core of the rock city near the lodge and in Prachov at the eastern entrance). Both institutions have been operating since the communist times.

Although the Prachov Rocks are an area that attracts tourists primarily with the sandstone landscape, there is little information about the local geological structure and sculpture. The above-mentioned tourist information points play a fundamental role - in addition to publications, in both there are educational panels with basic data. However, they do not refer to specific objects that tourists will pass on their way. There is no educational trail created in the reserve, although in various places (e.g. in the Emperor's Avenue), there are small panels with contents referring to natural environment (also tourism development in the area). Most of the attention is devoted to the lively nature; hence, it must be stated that the potential resulting from the local geology and relief is not properly used. In principle, a tourist does not even get the knowledge about processes that led to the destruction of sandstones and the creation of recent sculpture. Such proportions are also perfectly illustrated by the website dedicated to the Prachov Rocks. In the section on nature (Schlik n.d.), biotopes typical for the reserve are presented; however, little attention is paid to the specific habitat conditions created due to the presence of rocks, niches, ravines and caves. A lot of space is devoted to the reconstruction of the species composition of the forestspruce is replaced by fir, pine and deciduous species. The efforts to restore the Prachov Rocks landscape from the beginning of the twentieth century should be considered as a positive action for the interpretation of geoheritage. Following the limitation of forest management in the 2 nd half of the twentieth century, the rocks disappeared in tall tree growth with no underbrush (Schlik n.d.), while nowadays actions are aimed at better displaying them (which is carried out together with species exchange). As a result, individual forms and processes will be hopefully more visible. Along the routes, there should be more information about geoheritage, for example, referring to the characteristics of sandstone building the area, rubble caves or cell structures (honeycomb weathering).

\section{Adršpach-Teplice Rocks National Nature Reserve}

Main starting points for hiking in the Adršpach-Teplice Rocks are the city of Teplice nad Metují in the east and the village of Adršpach in the north, while the complementary role is played by Janovice in the west and a recreation settlement Skály in the south (Figs. 7 and 8). The railway line mentioned above does not reach only the latter location. In the reserve, one can move only along official marked tourist trails. In each of the two parts of the reserve, there is a main trail, providing access to the most attractive places (Fig. 3). Both have a semi-circular form, and the entrance is paid, with the cash offices at two main gates leading from the parking lots in Adršpach and Teplice. On the 6-km-long route in the Teplice Rocks, one can admire about 70 rocky towers. The walking time is approximately $3 \mathrm{~h}$. The main route in the Adršpach Rocks is $4 \mathrm{~km}$ long, and it takes $2-3 \mathrm{~h}$ to cover it (including a boat ride on an artificial pound called Adršpašské jezírko at the farthest point from the ticket office). However since 1980s, the network has undergone major changes that reflect the alterations in the way the nature reserve is generally made accessible.

The network of hiking trails in the Adršpach-Teplice Rocks did not change between 1974 and 1989, however, in that period it looked completely different than in the 1990s (Fig. 7). It was more extensive and provided more convenient connections. First of all, access to the central part of each of the rock cities was possible from various directions. The most attractive areas of Teplice Rocks in 1974 or 1989 could be reached from five directions, while in 1993 only from three, whereas in the case of the Adršpach Rocks at the same time there was a drop from as many as seven to only two directions. The liquidation of several trails at the beginning of the 1990s was conducted on the basis of a proposal by the tour operators. Main purpose was the separation of paid routes from those that were not charged in order to prevent tourists from visiting 


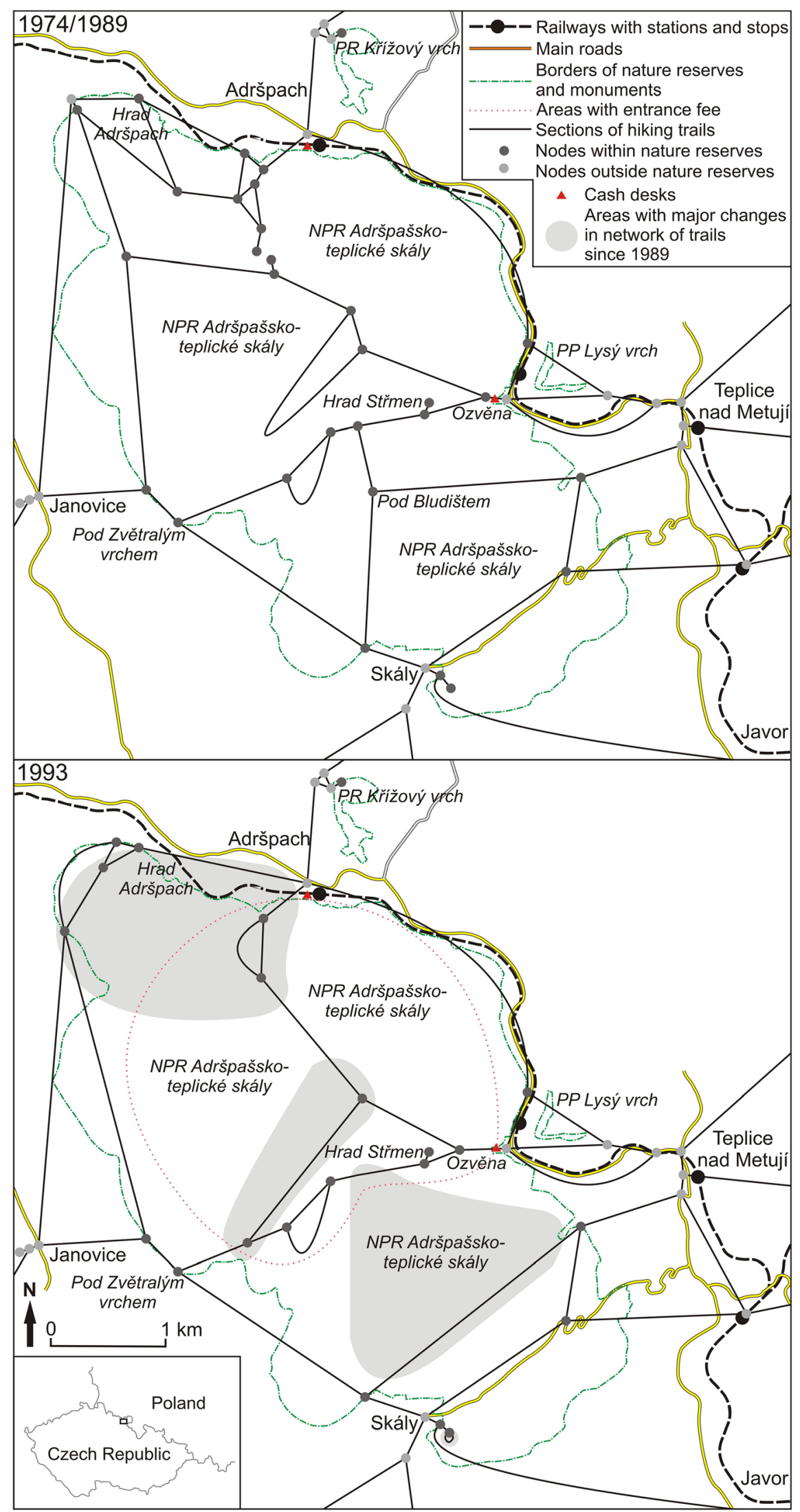

Fig. 7 Network of hiking trails in the Adršpach-Teplice Rocks National Nature Reserve in 1974, 1989 and 1993. Note: the network of trails in 1974 and 1988 was identical. In 1993, the area surrounding presented nature reserves and monuments was protected as the Broumovsko Protected Landscape Area (established in 1991). Based on: (Kartografie 1975; Kartografie Praha 1991; Vojenský kartografický ústav 1993) 


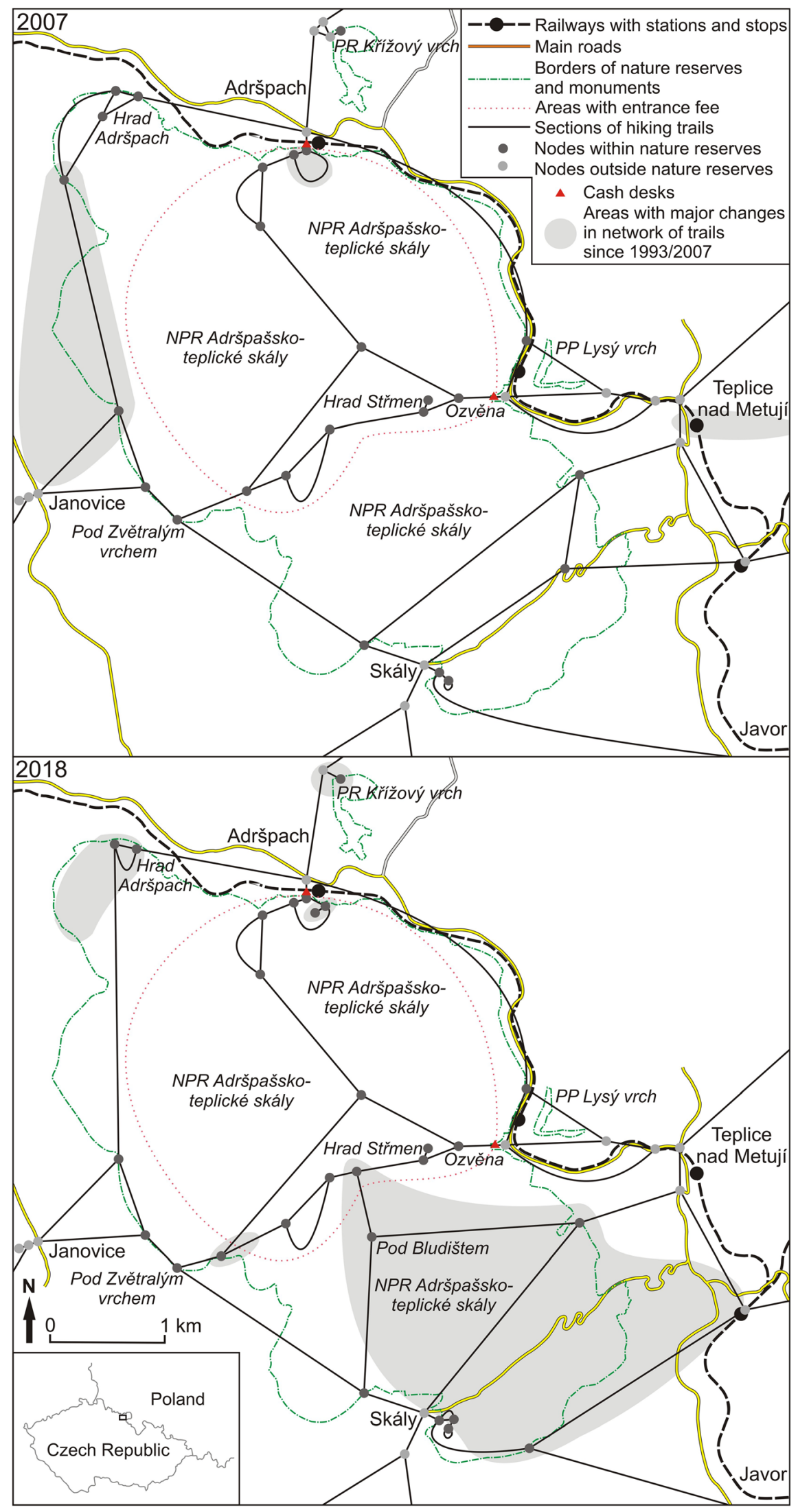

Fig. 8 Network of hiking trails in the Adršpach-Teplice Rocks National Nature Reserve in 2007 and 2018. Note: the area surrounding presented nature reserves and monuments is protected as the Broumovsko Protected
Landscape Area (established in 1991). Based on: (ExpressMap 2007; Seznam.cz n.d.) 
Table 5 Coefficients characterising networks of hiking trails in the Adršpach-Teplice Rocks National Nature Reserve between 1974 and 2018

\begin{tabular}{lllll}
\hline Coefficient & \multicolumn{4}{l}{ Year } \\
\cline { 2 - 5 } & $1974 / 1989$ & 1993 & 2007 & 2018 \\
\hline Total length (in km) & 39.8 & 34.9 & 36.5 & 37.7 \\
Density of trails (km/km ${ }^{2}$ ) & 2.21 & 1.94 & 2.02 & 2.09 \\
Number of nodes & 28 & 20 & 23 & 26 \\
Number of sections & 43 & 33 & 37 & 40 \\
Kansky $\beta$ coefficient & 1.54 & 1.65 & 1.61 & 1.54 \\
Kansky $\gamma$ coefficient & 0.55 & 0.61 & 0.59 & 0.56 \\
$\mu$ cyclomatic number & 15 & 13 & 14 & 14 \\
$\alpha$ coefficient & 0.29 & 0.37 & 0.34 & 0.30 \\
\hline
\end{tabular}

Note: the network of trails in 1974 and 1988 was identical

both main trails (with an expensive infrastructure) without paying. ${ }^{2}$ It was not primarily a matter of preventing tourists from entering any valuable, naturally protected locations. But as a result in some parts of the reserve, the nature conservation conditions actually improved, especially in the western section in Vlčí Gorge or in the area of the Świdnica Tower. The aim of all changes in that period was to channel the tourist traffic, so that as many people as possible would enter the protected area through the ticket offices at car parks in Teplice and Adršpach. Essentially, this seems a good solution, but it has concentrated a large number of tourists on specific routes, while earlier they could have been dispersed over a larger area. Of the two options: concentration or scattering of tourist traffic (Kowalczyk 2009; Kowalczyk and Derek 2010), the first one was chosen. This corresponds with the network changes and is well reflected in the numbers presented in Table 5. The length of the network within the AdršpachTeplice Rocks reserve decreased in the period 1989-1993 from 39.8 to $34.9 \mathrm{~km}$, the number of nodes-from 28 to 20 , and the number of sections of routes between nodes - from 43 to 33 . The density of trails referring to the protected area decreased from 2.21 to $1.94 \mathrm{~km} / \mathrm{km}^{2}$.

In the Teplice part only a short, $800 \mathrm{~m}$ section was liquidated; however, it was crucial to tourist movement organisation in this area. It connected the main tourist route stretching along the Skalní potok stream with trails further south, passing through the village of Skály, the Mt Čap (highest point of the nature reserve) and the Lokomotiva rock formation and viewpoint. People wandering through these areas were now forced to overcome long distances without being able to go to the

\footnotetext{
${ }^{2}$ Although these changes occurred in 1990s, fees have been collected for the entrance to the area since both main circuits were opened and guide activities were introduced, so since the first half of the nineteenth century. Otherwise, the first written evidence that the owner of the estate of Adršpach can charge for the entrance to the rocks is from 1926 and is connected with the decision of the State Land Office in Prague in the period of the first land reform.
}

standard sightseeing route. On the other hand, tourists who, after purchasing a ticket, walked along the main route had no possibility to continue the trip in other parts of the protected area (with exception for the passage through Vlčí rokle leading to the Adršpach part). In the north-western fragment of the reserve, liquidation in the years 1989-1993 covered the total length of $4 \mathrm{~km}$ of tourist trails and, as a consequence, most of the valleys so far available to tourists were closed. It is also worth noting that in 1989 there was no route around Adršpašské jezírko pound and tourists who wanted to travel between two parts of the reserve were forced to use boats running on the reservoir. In 1993 such a trail-leading across narrow valleys - already existed. So on one hand, in some of the valleys, the routes were liquidated, but on the other-a new one was created elsewhere. In 1993, in relation to 1989, the network of trails on the north-western edge of the reserve (the area with relicts of the Adršpach castle) was also transformed, which was a consequence of the liquidation of routes running there from the south-east.

No new routes were created at the beginning of the twentyfirst century, except for a short (only $1 \mathrm{~km}$ ) circular trail around the flooded sandbank directly next to the entrance to the Adršpach Rocks (Fig. 8). Because the area around the reservoir had undergone significant transformations in the recent past, further human interference has not been a significant problem. Furthermore, until 2007, two trails changed their route in the vicinity of the analysed reserve (Fig. 8) due to the liquidation of field roads they led. In total, the length of the network within the boundaries of the reserve increased until 2007 only by $0.8 \mathrm{~km}$, the number of nodes by three, and the number of sections by four (Table 5). The density of trails grow slightly up to $2.02 \mathrm{~km} / \mathrm{km}^{2}$. Major changes began in recent years, as can be seen on the map showing the situation in 2018 (Fig. 8). The most important thing is the reopening of the abovementioned short section in the Teplice Rocks, thanks to which the local network regained its integrity. The reason for the renewal of the section U Sekery - Pod Bludiště was the interest of the town of Teplice nad Metují in increasing the attractiveness of the main circuit by connecting it with the new lookout tower at Č́p, resp. creating a legal, marked link between the Teplice Rock City and the new tower. It was mainly a political decision of the city representatives - to create more opportunities for visitors to the territory. Till 2018, the length of marked trails on the southern edge of the reserve has also increased, because the yellow marked walking route connecting the settlement of Skály with Teplice, which had been running almost entirely along a regular road opened to all traffic, has been redirected on the forest and field paths more to the south. Using partly its previous course, another, blue marked walking trail was extended. In the same time, the network in the most north-western part of the reserve, near the Adršpach castle, was further reduced. It resulted from significant isolation of this area (connection with the rest of the network by one route only) 
and - as a consequence - its low popularity. When in 1993 and 2007 a node of trails existed there, nowadays only a short, circular access route leads to the ruins. Moreover, the offer of short walking routes near the Skály settlement has been slightly expanded. The result is an increase in the length of the network of marked hiking trails within the Adršpach-Teplice Rocks National Nature Reserve from $36.5 \mathrm{~km}$ in 2007 to $37.7 \mathrm{~km}$ in 2018 (Table 5), which is a little higher than at the end of the communist period. Slightly smaller is the number of junctions of routes and sections between them, as well as the density, reaching $2.09 \mathrm{~km} / \mathrm{km}^{2}$. However, it is worth paying attention to the preservation of large areas devoid of the network of routes, and thus interference from tourists (Fig. 8). This is primarily the north-western and north-eastern parts of the nature reserve (the western and eastern parts of Adršpach Rocks) and the south-eastern part of the protected area (the south-eastern part of Teplice Rocks). However, the problem remains the illegal dispersion of tourists who often go through valleys excluded from tourist traffic, especially in the western part of Adršpach Rocks, what is clearly visible in the period with snow cover.

The presented changes in the shape of the network and the course of the routes resulted in fluctuations of the values of the basic indicators characterising network integrity (Table 5). At the turn of the 1980s and 1990s, there was a significant decrease in the number of nodes and edges (sections) between them, respectively, by less than $30 \%$ and $25 \%$. In the following years, these numbers slowly increased to reach today's values quite close to those from the late 1980s, although still a bit lower, which is justified taking into account the needs of nature conservation. The liquidation of routes or their fragments at the beginning of the examined period proceeded in such a way that the number of edges decreased slower than the number of nodes. A deletion of one section usually resulted in a liquidation of both nodes connected with it, because no other routes started in these places. From both of these junctions, before the changes, tourist trails went out in three directions and liquidation of one route meant that only two directions remained. The consequence is the seemingly surprising increase in the coherence of the studied network of trails along with limiting the number and length of routes. The value of the $\beta$ coefficient increased from 1.54 in 1989 to 1.65 in 1993, and the value of $\gamma$ index, illustrating the proportion between the existing and the potential number of sections (resulting from the number of nodes), from 0.55 to 0.61 . In spite of this apparent growth, one must remember that the shape of the network and the layout of individual routes are extremely important. This was the period of limiting access to paid parts of the reserve, which significantly restricted the possibilities of planning trips in the studied area. Nowadays, despite the fact that the number of sections and nodes is slightly smaller than in 1989 , the cohesion of the network is comparable to that from the end of the 1980s. Despite changes in the values of individual graph indicators, presented network of tourist trails in each of the analysed years can be included to the lattice system, quite well developed and coherent, which reflects the popularity of the place among tourists, but is in conflict with the nature of the protected area, where accessibility should be limited. In the case of the Adršpach-Teplice Rocks, only admission fees and exclusion of selected parts of the reserve from tourist penetration are examples of such restrictions. It is also worth mentioning that the values of all coefficients characterising networks are very similar for both AdršpachTeplice and Prachov rock cities.

The tourist infrastructure of the Adršpach-Teplice Rocks in the communist period was focused on individual tourists to a slightly greater extent than in the case of the Prachov Rocks. This is evidenced by the existence of a large campsite Bučnice at a distance of only $500 \mathrm{~m}$ from the entrance to the Teplice Rocks and a large number of holiday houses (second homes) in nearby settlements (Teplice, Skály, Adršpach, Zdoňov, Dědov, Česká Metuje). It does not change the fact that the tourist traffic at that time should be considered mass, because many tourists come there only for 1 day, using the railway line that surrounds the reserve from the west, north and east. The train station in Adršpach is located directly at the entrance to the rock city, while in Teplice, a special passenger stop was created for this purpose. A marked tourist trail leads from each of the nearby railway stations to at least part of the analysed reserve. During the communist period, five hotels functioned around the protected area (one in Adršpach at the entrance to the rock city, the rest in Teplice, including one at the entrance to the paid tourist route), also two hostels (Teplice and Adršpach) and many company holiday facilities, available only to people employed in a given workplace (there were many of them especially to the north-east of the reserve).

As a result of the political transformation, the accommodation offer has changed significantly. Bučnice campsite is still functioning, which results from its excellent location both when it comes to access to the facility itself, as well as access to the rock city. A second, small campsite was also established in Teplice. Only one of the hotels mentioned above survived- "Orlík" at the entrance to the Teplice Rocks (although in some years it was opened only in the summer season). Despite the persistent high tourist traffic, other hotels did not manage to stay in business, although one of them in recent years has been reopened after a major refurbishment. Facilities owned by companies were either liquidated or, what was much more frequent, transformed into facilities open to wide public. A lot of small guesthouses have been created, and there is a large number of houses for rent. Nowadays, the accommodation offer related to the Teplice Rocks is better developed than in the case of the Adršpach Rocks, but in both cases - in contrast to the communist period - small objects dominate. Some facilities are seasonal, especially catering in Adršpach. The vast majority of tourists wandering around 
both presented rock cities, however, do not stay in the area. They are arriving there using a very well-developed public transport or cars. In the latter aspect, the problem is the limited number of parking spaces in Teplice, where the car park is located in a narrow valley. Although it has a slightly different character than in the Prachov Rocks, the tourist infrastructure of the analysed area corresponds with the intense tourist traffic, and its location intensifies the pressure on the protected assets. A positive aspect is the promotion of public transport as means of travel in order to visit the Adršpach-Teplice Rocks - a good network of connections and short access from railway stations are surely encouraging.

Information and education related to geosciences in the Adršpach-Teplice Rocks is better developed than in the case of the Prachov Rocks. However, also in this protected area, there is no museum focused on this subject (in the palace in Adršpach, there is only a small museum dedicated to mountaineering in the local rocks). An educational path Naučná stezka Josefa Vavrouška (Fig. 9) plays a fundamental role in the Teplice Rock City. The trail was established in 1999 and runs along the blue marked tourist trail (so the main tourist circuit). It contains 17 information boards that include not only texts about the history of discovering the rock city and landmarks from the plant and animal kingdom, but also a large number of photographs and illustrations. Among geoheritage topics are local geology and rock layers, the process of weathering sandstones and the creation of rock cities, caves in sandstone landscapes, microforms on sandstone surface, local hydrology, fossils and conditions for rock climbing. In 2009 to original 15 boards, one additional was added, which informs about the cave system called Poseidon, the longest European underground system in sandstone. At the beginning of 2016, all panels were replaced with new, updated ones. The path discusses all natural issues of the Teplice Rocks, also related to geology and geomorphology, paying attention to mutual dependencies, e.g. specific habitats for plants among rocks. The most important texts from the panels were translated into English and Polish.

Surprisingly, no didactic path was created in the second part of the reserve. In Adršpach, only an educational path leading north, to the top of Mt Krrížový vrch, begins. It is enriched with interactive elements on three information panels. The 1.4-km-long trail leads to a steep hill with several rock towers, named after the Way of the Cross, which was created in the seventeenth century. There is also the Bischofstein educational trail in the settlement of Skály, which is indirectly connected with geoheritage. It discusses conditions of settlement among rocks, in a diversified landscape, and the use of natural defence of rocks for the construction of a castle. Finally, the Sudetes Georoute leads along the main road surrounding the Adršpach-Teplice Rocks from north and west (Bartuś et al. 2009). This is a 600-km-long car tourist trail created in 2013 by the Lower Silesian Branch of the Polish Geological Institute and the Czech Geological Survey (some parts can be visited by bike and occasionally on foot). Running on both sides of the national border, it provides tourists with 21 information boards. Additionally, there were prepared: a geological tourist guidebook, 21 information leaflets and a website www.geostrada.eu (Cwojdziński et al. 2011; Stachowiak et al. 2013). Because of specialist language used in some parts of the guidebook and on several panels, the Sudetes Georoute is actually dedicated mainly to geologists, geomorphologists and tourist already knowing the region and its geology (Rogowski 2016). More geotourist information on the Adršpach-Teplice Rocks can be obtained from tourist information centres in two main settlements. In the case of Adršpach, the centre is very conveniently located between the railway station and the car park, and the entrance to the paid tourist route. The building, however, is not large enough for high tourist traffic during the summer season. In Teplice, the information point is located in the city centre, $1.5 \mathrm{~km}$ from the entrance to the rock city. Although the geotouristic potential of the Adršpach-Teplice Rocks is better utilised than in the
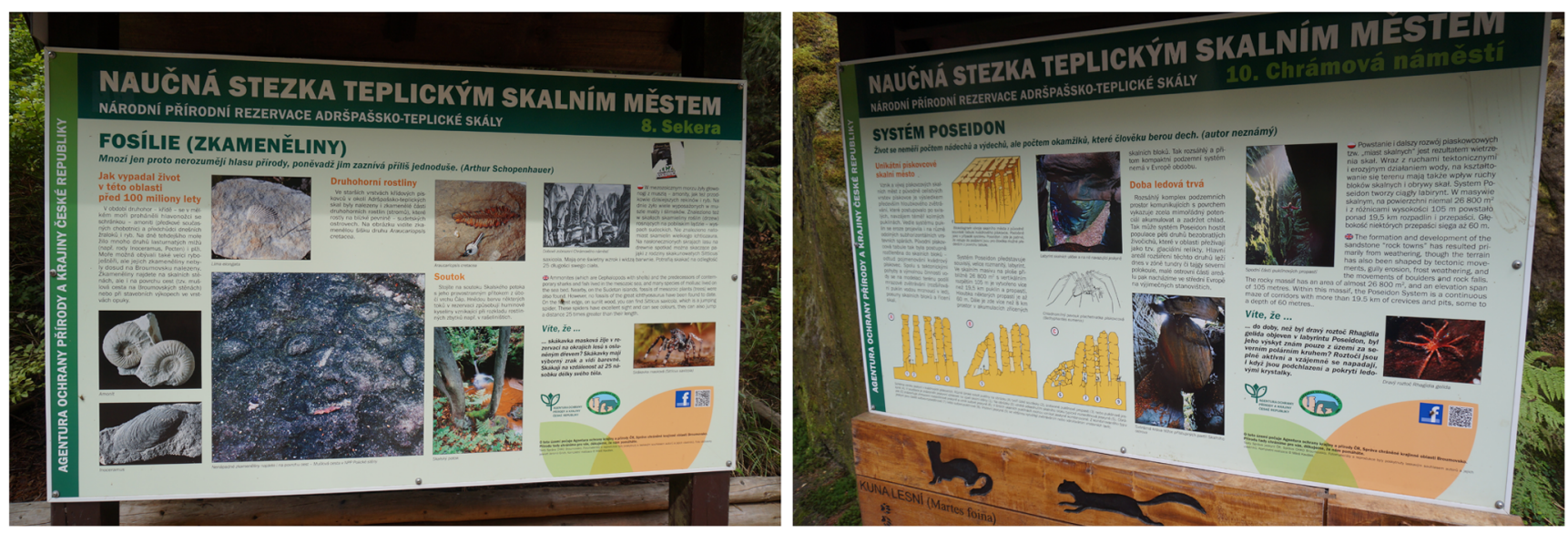

Fig. 9 Selected panels of the educational path in the Teplice Rock City 
case of the Prachov Rocks, there is still much to do, especially in the north-western part of the protected area, where there is no educational offer. A positive aspect should be considered the discussion of various phenomena at the place of their occurrence, what makes it easier to understand the transmitted content.

\section{Table Mountains National Park}

In 1988, at the end of the communist period, the network of hiking trails in the Table Mountains was poorly developed (Fig. 10) as regards the length of the routes, although it was characterised by fairly high cohesion (density of only $1.11 \mathrm{~km}$ of trail per sq. $\mathrm{km}, \beta$ indicator with a value of up to 1.95 ; Table 6). Moreover, it did not change since first half of 1980 s and only slightly since 1970s (Państwowe Przedsiębiorstwo Wydawnictw Kartograficznych 1974, 1985). In that whole period, there were only a few marked hiking trails throughout the area of today's national park; however, they connected quite effectively all the main attractions (Mt Szczeliniec Wielki, Błędne Skały Rocks, Skalne Grzyby Rocks, and Białe Skały; Fig. 4). At the same time, many places were not made accessible by tourist routes, mainly in the south-western part of the area and near the northern escarpment, which is characterised by outstanding landscape and geotouristic values. Many viewpoints located along the edge, known and functioning before the Second World War, in the late 1980s were not made accessible by tourist trails. This changed only in the following years. There are several reasons for the short length of tourist routes during this period. First of all, the Table Mountains in that time were protected as a landscape park, where - in contrast to a national park - there is no prohibition to move outside the marked tourist trails. Therefore, one could theoretically wander along all existing roads, what was even encouraged in tourist guidebooks (e.g. (Martynowski and Mazurski 1988)). The problem in this aspect, however, was the lack of accurate maps. Secondly, the Table Mountains lie in the border zone, what in the communist period meant restrictions in movement. Although in 1988 the restrictions were much smaller than immediately after the communistic putsch, the network of routes still reflected them to some extent (the restrictions were partially restored during the martial law in the early 1980s). During the communist period, in the whole Polish Sudetes only a few tourist trails were created along the border, of course without the possibility of entering the neighbouring country (Kołodziejczyk 2014a). Until the mid-1950s, no routes were created in the belt between the last road in the country and the state border, and by the end of the 1960s there were no trails running exactly along the state border. In the Table Mountains, marked routes nevertheless approached the border already in the first years after the war (but their network still was poorly developed). It resulted from the location of one of the main attractions - the Błędne Skały Rocks - only a few metres from the state border. Also, the tourist lodge in Pasterka was situated relatively close to Czechoslovakia. Already in the 1970s there was a route from Kudowa-Zdrój to Karłów through Pstrążna, the Błędne Skały Rocks and Pasterka, which in several places approached the border only a few metres away (Fig. 10; Państwowe Przedsiębiorstwo Wydawnictw Kartograficznych 1974). As the third reason for the small length of the network in 1988, it is possible to indicate a relatively low popularity of other parts of the Table Mountains except for Mt Szczeliniec Wielki and the Błedne Skały Rocks, to both of which mainly organised mass tourism was directed.

In subsequent years, the network of hiking trails significantly expanded (Fig. 10). The length of routes increased from $70.6 \mathrm{~km}$ in 1988 to $98.8 \mathrm{~km}$ in 2004, the number of nodes in the same period more than doubled from 20 to 42 , and the number of sections between them increased from 39 to 73 (Table 6). This resulted mainly from the creation of the national park and, on one hand - the increase of the popularity of the area, and on the other - the introduction of a ban on moving outside the marked trails. Considering the limitations of the previous network, in order to ensure the possibility to reach a number of attractive locations, mainly of geotouristic nature, it was necessary to create new tourist trails. The title of a national park is a distinction. The Table Mountains became the 17th national park in Poland, while there were several dozen landscape parks in that time. As a result, the interest of tourists in this area increased significantly, although the attractiveness has obviously not changed. This was reflected in the larger tourism movement. The area had to be prepared for it, including development of infrastructure, together with the network of hiking trails. In order to reduce illegal dispersion and counteract excessive concentration of tourists in some of the most popular places, routes were marked in areas that were so far less known (mainly south-west of the national park). The result was - seemingly surprising - a rapid development of the network of official routes despite the growth of the protection regime. An additional factor was the successive opening of state borders. The first step in this matter was the creation of the so-called tourist border crossings, and the next - the entry of Poland and the Czech Republic into the Schengen Area on December 21, 2007. By 2007, two tourist border crossings were created within the national park area and next two were opened in its vicinity. Hiking trails had to be marked to each of them, what additionally contributed to the development of the network and its connection with routes on the Czech side of the border (Figs. 10 and 11). The extension of the Schengen Area allowed for further integration of the Polish and Czech networks of routes, which was marked mainly in the western part of the national park, especially around the Błedne Skały Rocks (Fig. 11). Among others, a trail crossing the state border as many as four times was created, connecting attractions and settlements on both sides. 


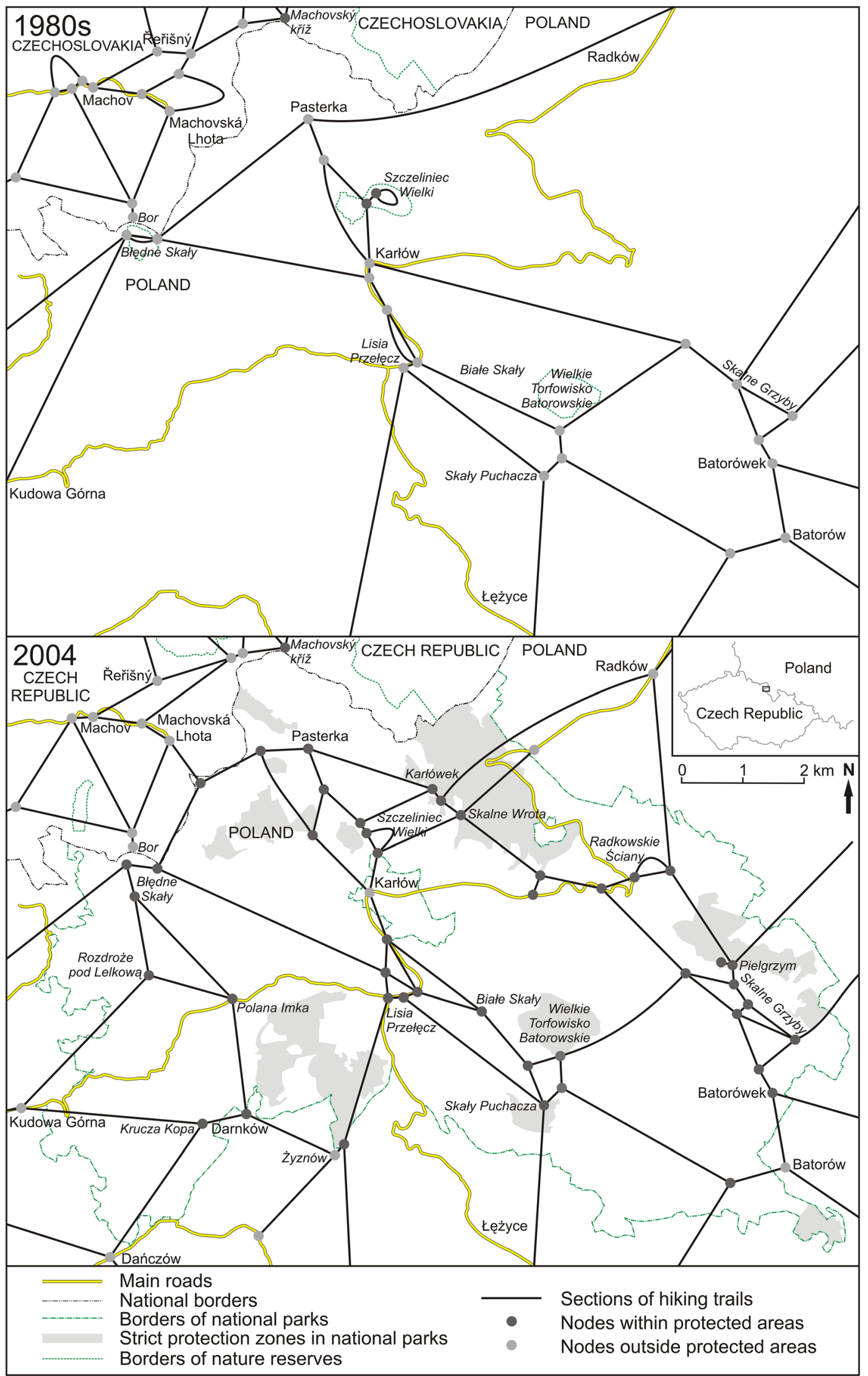

Fig. 10 Network of hiking trails in the Table Mountains in 1980s and in the Table Mountains National Park in 2004. Based on: (Martynowski and Mazurski 1988; Kartografie Praha 1991; SHOCart 2008) 
Table 6 Coefficients characterising networks of hiking trails in the Table Mountains and the Table Mountains National Park between 1980s and 2018

\begin{tabular}{lllll}
\hline Coefficient & \multicolumn{3}{l}{ Year } & \\
\cline { 2 - 5 } & $1980 \mathrm{~s}$ & 2004 & 2007 & 2018 \\
\hline Total length (in $\mathrm{km})$ & 70.6 & 98.8 & 103.9 & 104.0 \\
Density of trails $\left(\mathrm{km} / \mathrm{km}^{2}\right)$ & 1.11 & 1.56 & 1.64 & 1.64 \\
Number of nodes & 20 & 42 & 53 & 56 \\
Number of sections & 39 & 73 & 91 & 96 \\
Kansky $\beta$ coefficient & 1.95 & 1.74 & 1.72 & 1.71 \\
Kansky $\gamma$ coefficient & 0.72 & 0.61 & 0.59 & 0.59 \\
$\mu$ cyclomatic number & 19 & 31 & 38 & 40 \\
$\alpha$ coefficient & 0.54 & 0.39 & 0.38 & 0.37 \\
\hline
\end{tabular}

Note: The values for 1980 s were calculated taking into account the contemporary boundaries of the Table Mountains National Park (the park did not exist then)

The development of the network of hiking trails corresponded with the activities aimed at proper control of the tourist traffic. Connecting routes were established, starting at the parking lots situated along the scenic Road of One Hundred Curves. Attention should be payed to the situation near the Błędne Skały Rocks. The rock city itself can be reached by car; however, the car park has a limited capacity, in addition, the traffic on the only access road is carried out alternately up or down every $30 \mathrm{~min}$. At the Road of One Hundred Curves, an additional car park was created, which was connected with the Błędne Skały Rocks by two marked routes: an ordinary hiking trail and an educational path (compare Figs. 10 and 11). They run different ways; hence, the possibility of planning a circular trip is ensured. Entrance to the Błędne Skały Rocks is payable. In the past, two sightseeing routes led through the rock labyrinth (with several variants), one of which was finally closed (Fig. 10). To improve traffic, the remaining route is unidirectional, while the return to the car park is carried out through a recently built bypass on the northern side of the stone labyrinth (compare Figs. 10 and 11). The density of trails in the vicinity of Karłów increased to provide an alternative for the overcrowded Mt Szczeliniec Wielki. As for the tourist route at its top, a new southern descent from the plateau was built (Fig. 10). Thanks to this, the existing western entrance may be used almost exclusively for the purpose of climbing to the mesa's top (it is used as a return way only by those who go to the tourist lodge and do not enter the main route). Moreover, the paid route within the plateau was shortened. Unfortunately, not all areas of strict protection are excluded from tourist penetration. At Mt Szczeliniec Mały or in the Great Batorów Mire tourists are not allowed (in the latter case also for security reasons), but the Puchacz Rock, the Skalne Wrota area and the Pośna valley are available due to their quite high popularity and the need to create a coherent network of tourist trails. This is a typical problem for protected areas that were established in a well-known places in terms of tourism, with a pre-shaped network of popular destinations and tourist routes. Any attempts to limit the availability of selected places may meet with objections among tourists, and even cause the opposite effect, as some people will try to get there unlawfully, outside marked trails. A similar situation took place in another area built of sandstones - the Czech Switzerland National Park (Kołodziejczyk 2017c), which was established on February 1, 2000 as a result of a transformation of the most valuable part of the Labské pískovce (Elbe Sandstones) Protected Landscape Area. By the way, it is worth noting that in both the Czech Switzerland and the Table Mountains national parks, no general fees for entering the protected area have been introduced. Tickets are only for visiting the main attractions.

The network of hiking trails in the Table Mountains National Park is the longest one discussed in this article (Table 6). Even in 1988, when it was still poorly developed, the length of routes was almost twice as long as in the aforementioned nature reserves. However, this results from a much larger area. For example, the Table Mountains National Park is over three times larger than the Adršpach-Teplice Rocks National Nature Reserve. As a consequence, the density of trails in 1980 s was only $1.11 \mathrm{~km}$ per sq. $\mathrm{km}$. In the period 1988-2018, the length of walking routes increased 1.5 times, from 70.6 to $104.0 \mathrm{~km}$ and the density grew up to 1.64 . In the same time, the number of nodes increased almost three times from 20 to 56 , and sections between them-almost 2.5 times from 39 to 96 . A larger increase in the number of nodes than sections caused - similarly as in the case of the Prachov Rocks - a drop in network's cohesion (value of the $\beta$ indicator dropped from a very high value of 1.95 in 1988 to about 1.7 in 2004-2018, and the $\gamma$ coefficient from 0.72 in 1988 to around 0.6 in 2004-2018). This resulted from the creation of many nodes from which routes spread only in three directions (what reduces cohesion), while at the end of the 1980s, there were many nodes from which marked trails led in as many as four directions. It is worth noting that despite changes in the route network in the twenty-first century, the values of $\alpha, \beta$ and $\gamma$ graph coefficients have remained at a similar level. Considering the classification of a network according to Taafee and Gauthier (1973), modified by Styperek (2001), the network of hiking trails in 1988 should be classified as the most coherent delta system, while in other analysed years - as the lattice system. Seemingly, these changes correspond positively with the increase of the area's protective regime. The landscape park had a more coherent network than the national park. In reality, however, it must be remembered that the network of routes is now much longer and denser than in the 1980s. The indicators drawn from the graph theory do not always describe adequately all transformations of networks, especially in areas with many natural limitations in the creation of subsequent sections of routes (e.g. precipices, boulder fields, wetlands).

The tourist infrastructure of the Table Mountains has always been predestined by the existence of three large spas 


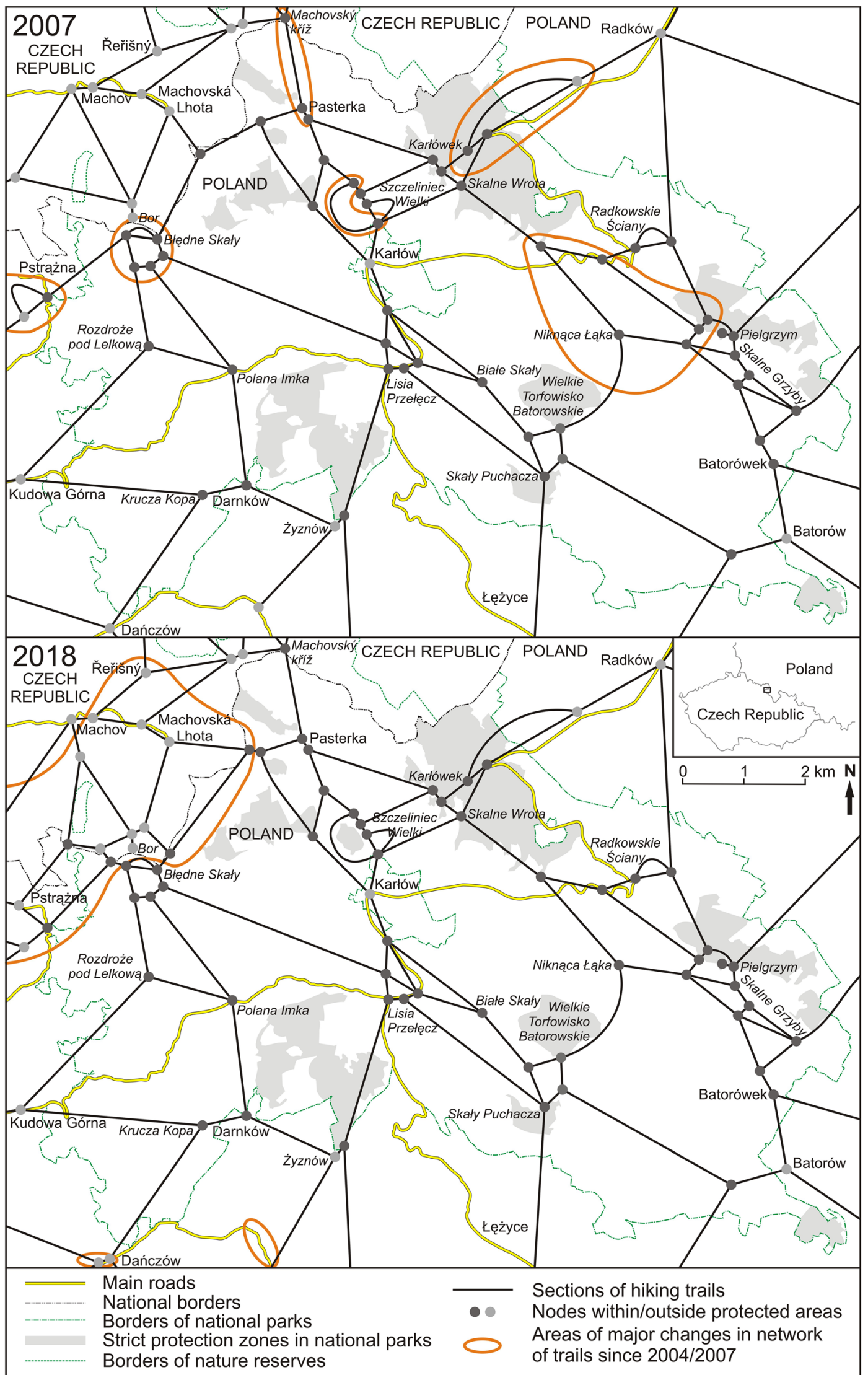

Fig. 11 Network of hiking trails in the Table Mountains National Park in 2007 and 2018. Based on: (Plan 2007; ExpressMap 2007; Mapa turystyczna n.d.) 

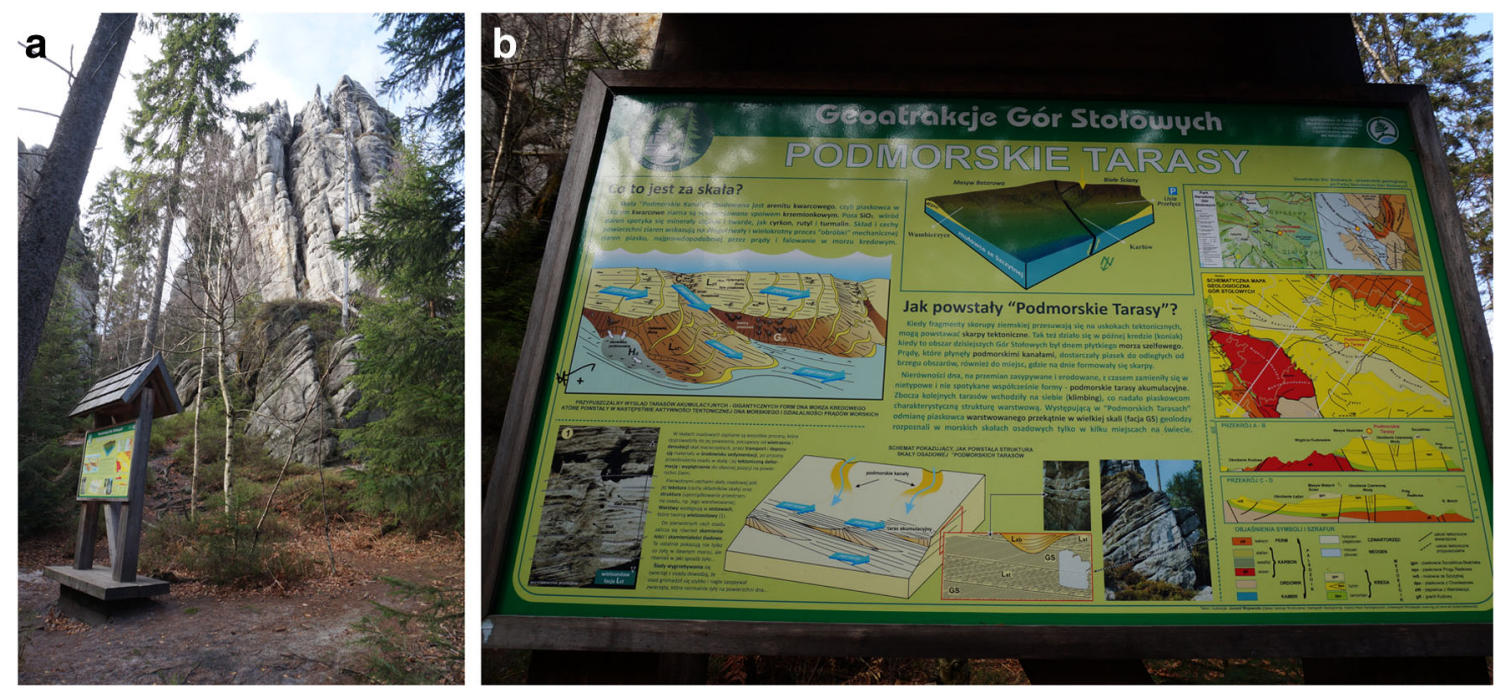

Fig. 12 Educational panels "Geoattractions of the Table Mountains". a Location of the panel "Submarine canals" near the Białe Skały Rocks. b Example of a panel

on the south side of this mountain range (Kudowa-Zdrój, Duszniki-Zdrój, Polanica-Zdrój). In these three cities, there is a high density of accommodation and catering facilities, and it is there that a large part of tourists wandering around the national park stay for the time of their visit. Because these spas take over a significant part of tourist traffic, the zone north of them towards the border of the national park was for a long time characterised by a very poor development in terms of accommodation facilities. It was not until the last years that guesthouses started to be built there, especially in Łężyce. As far as the main area of the Table Mountains is concerned, the tourist infrastructure is concentrated in Karłów, which is located in the centre of the mountain range, constituting a non-protected enclave within the national park. This is where trips to Mt Szczeliniec Wielki begin, as well as wanderings to other parts of the range. During the communist period, company holiday resorts prevailed there, some of which survived to this day, but nowadays smaller guesthouses compete with them. Closed a few years ago, a large holiday resort, located partly in a stylish former forestry building, was taken over in 2017 by the national park authorities, which opened the hotel again. A lot of accommodation facilities (holiday centres, campsites, camping houses), created during the communist period, are located at the northern edge of the Table Mountains, on the outskirts of the town of Radków, at the Radkowski Reservoir. After the crisis in the period of systemic transformation in Poland, in recent years, these objects are being renovated and their standard is being raised. With exception to Karłów, the tourist infrastructure in the Table Mountains is located not as close to the protected area's borders as in the case of the Prachov Rocks and the AdršpachTeplice Rocks. It is also less developed. The proof may be a comparison of the complex of campsites at the ponds on the north-eastern side of the Prachov Rocks with much smaller, as regards the area and the number of beds, facilities over the Radkowski Reservoir. However, Karłów itself interacts very intensively in terms of landscape, flora and fauna protection. In recent years, the infrastructure there has been undergoing constant expansion - new guesthouses, catering facilities, souvenir shops and even a dinosaur park have been built. These objects disturb the landscape of the central part of the national park due to their number, size and form.

Due to the unique sculpture, as in the case of previously described protected areas, in the Table Mountains, there is a large number of facilities enabling visits to attractive geotourist sites, e.g. viewpoints. The most numerous are stairs carved out in rock, sometimes with barriers, and footbridges over wetlands and peat bogs. A short section of trail equipped with a chain in the area of the Puchacz Rock is particularly spectacular. Some of these devices remember the beginnings of tourism in the Table Mountains, others are contemporary. There are several rain shelters, especially in the marginal parts of the national park. Recently, large wooden signposts have been installed at the crossroads of the routes of various types (hiking, cycling, skiing). Due to their height (about $2 \mathrm{~m}$ ) and massiveness, they seem inappropriate in the protected area with a fairly high regime, especially because their form is inconsistent with the rules adopted in Poland for marking tourist trails. The Table Mountains are characterised by good accessibility for motorised tourists. Some roads themselves have a sightseeing value, such as the Road of One Hundred Curves, crossing the whole range from the south-west to the north-east (from Kudowa-Zdrój to Radków), built with a large workload in 1867-1870. Accessibility of the area for non-motorised tourists is worse (Kołodziejczyk 2017a). The railway lines run a few kilometres from the borders of the national park and the offer of bus connections is better only in the summer season (Kołodziejczyk 2014b, 2017b). 
The Table Mountains can be proud of the probably oldest geotourist educational trail in Poland. The Rock Sculpture Path (Pulinowa 2000) was created in the 1980s, connecting Karłów with Radków through the rock labyrinth of Mt Szczeliniec Wielki, village of Pasterka and the Pośna river valley. The path is about $10 \mathrm{~km}$ long and on most of its course coincides with regular hiking trails. It consists of 14 didactic sites representing places most interesting in terms of geology in the Table Mountains (including various rock formations in the rock maze of Mt Szczeliniec Wielki, block streamsstreams of slowly moving rock blocks in the foot of the sandstone massif, the so-called Pośna Gate - gorge cutting through the northern escarpment of the Table Mountains). Because the path was created many year ago, not all of the content is consistent with the current state of knowledge (e.g. the origin of sandstone blocks at the foot of escarpments separating different levels of the Table Mountains; see (Duszyński et al. 2017; Duszyński and Migoń 2015; Migoń et al. 2018)). Moreover, the infrastructure associated with the route (markings of points of interest, waymarking) has been destroyed to a large extent. To travel through the Rock Sculpture Path, a guide is needed. Although it had several editions, it is now more and more difficult to possess. As a result, the possibility of using the path by casual tourists is quite limited.

Within the area of the Table Mountains National Park, there are two other designated educational paths, however, focused on lively nature (Park Narodowy Gór Stołowych n.d.). What is more important, considering the purpose of this article, in 2011, new educational panels presenting the geological structure and history of the Table Mountains were created (Fig. 12). They were located in places with extraordinary didactic values. There are six such sites in the whole park and they received a common name "Geoattractions of the Table Mountains" (Polish Geoatrakcje Gór Stotowych). The way to the panels from standard tourist routes is indicated by signposts (they do not form a continuous route, but are located in various places in the park). The boards should be prised for an attractive graphical form. Other advantages of this offer include the discussion of accurate phenomena exactly in places where one can observe evidence of their existence (e.g. processes occurring at the bottom of the Cretaceous Sea are illustrated by sandstones with various lithology and structure; the process of disintegration of the sandstone cover is discussed at its relics). The text part is accessible to people without geological education, worse with illustrations that require the ability to read a geological map or blockdiagrams. Moreover, a section of the Sudetes Georoute leads through the Table Mountains (Bartuś et al. 2009). The geoheritage of the Table Mountains was described in two guidebooks by Wojewoda (Wojewoda 2011; Wojewoda 2013b), and on geological tourist maps by Čech and Gawlikowska (Čech and Gawlikowska 1999), and Wojewoda (Wojewoda 2013a).
The geotourist infrastructure in the whole region on both sides of the national border (Table Mountains in Poland and Broumov Highland in the Czech Republic, including the Adršpach-Teplice Rocks) consists of at least nine educational paths with educational panels, various guidebooks and maps presenting geoattractions. In the Czech part, an initiative Broumovsko Geopark was created, and for its needs 44 geosites were described. Unfortunately, still there are little cross-border coordination activities. However, taking into account the potential, there is a big chance for the Table Mountains cross-border region to become the most recognised sandstone landscape in Central Europe (Rogowski 2016).

\section{Discussion}

In each of the analysed areas, during the period of political transformation (i.e. the end of the 1980s compared with the situation in subsequent years after transformation up to modern times), changes took place in terms of the management of the protected area and its provision to tourists, expressed in the changes of networks of tourist trails - their shape, coherence and total length. However, the character of these changes was different and conditioned by various local factors.

In the Prachov Rocks Nature Reserve, despite the return of the whole area to the pre-war owners, the existing model of land management has been largely kept unchanged. Only two short sections of walking routes have been liquidated. This area is probably the most popular and most visited complex of sandstone rocks in the Czech Republic; hence, attempts to limit accessibility could be met with dissatisfaction among tourists and intensification of illegal dispersion beside tourist trails. Together with intensive tourist development of the surroundings of the reserve (some facilities often adjoin the boundaries of the protected area), this causes intensive impact on nature. In the fragments of the rock city with the most attractive relief, a complicated network of artificial paths with stairs (partly carved into the rock), footbridges and handrails was created over the years. At the same time, however, several areas excluded from penetration were maintained (unfortunately, they are quite small).

In the Adršpach-Teplice Rocks National Nature Reserve, the key factor of changes of hiking trails network was the aim to separate paid routes from those not charged and a farreaching limitation of the possibility to enter the rock cities not using the routes equipped with cash offices and leading from the parking lots. The shape of the network had become very specific, which made it difficult for more ambitious hikers, including non-motorised tourists, to plan adequate trips. The consequence was the concentration of tourist traffic on two main routes, while other trails due to their peripheral location in the network became less popular. The aim was reached, but it resulted in the increase of devastation 
(including erosion) on both main tourist circuits. In recent years, however, a different tendency is noticeable and one of the liquidated trails has been restored. However, since the beginning of the 1990s, a significant part of the reserve has been closed to tourists.

Finally, in the Table Mountains throughout the analysed period, we had observed the continuous development of the network of trails, which resulted from the establishment of a national park in this area and - as a consequence - an increase in its popularity and, simultaneously, the introduction of a ban on moving outside the marked tourist routes. Opening of national borders also played a role in this case.

Liquidation of marked tourist routes in protected areas must result from objective premises and take into account long-term plans for shaping the network. Liquidation is simple, but restoring a tourist trail in a strictly protected area in the category of national nature reserve, the first zone of the protected landscape area, a site of European importance and the bird area of the NATURA2000 system may not be easy in the future, what was pointed out by the authorities of the Broumovsko Protected Landscape Area, which part is the Adršpach-Teplice Rocks National Nature Reserve. Therefore, in the event of damages, which after some time may give way or be removed (e.g. windbreaks or the effects of floods), it seems more appropriate to temporarily close the trail, not liquidate it.

Considering the density of the network of trails, the highest (almost $6 \mathrm{~km} / \mathrm{km}^{2}$ ) has been calculated in the case of the Prachov Rocks, which corresponds with a very intense tourist movement in virtually all of the protected area. Even at the time of the greatest development of the trails in the AdršpachTeplice Rocks, i.e. in the 1980s, the local network of hiking trails was about 2.5 times less dense. Currently, the difference is almost threefold. The lowest density is characteristic of the Table Mountains National Park $\left(1.64 \mathrm{~km} / \mathrm{km}^{2}\right)$, although this is a slightly misleading result, because on one side there are quite large areas without tourist trails (the first protection zone, swamps, areas along the relief edges), and on the other-areas where the number and length of marked routes is significant. The latter most often correspond to attractions most popular among tourists.

It is difficult to unequivocally assess which model of making sandstone protected areas accessible for tourist is appropriate. In that case, a questionnaire-based survey among tourists is needed, but also detailed documentation of trails, including biological survey of all signs of devastation (erosion due to overcrowded traffic). From the tourists' perspective, more extensive network of routes is desirable to allow easy planning of trips and access to potentially all interesting places (Dronka et al. 2014; Stasiak et al. 2014). From the point of view of nature protection (mainly plants and animals occurring among rocks), this is an undesirable situation (Styperek 2001, 2002). In the case of the Prachov Rocks and some parts of the Table Mountains, the network seems too extensive. The nodes of trails are sometimes less than $1 \mathrm{~km}$ apart. When in the second case we would take into account all public roads crossing the national park, as well as bicycle and ski trails (in other analysed areas, such trails are very short and appear in the marginal parts), the degree of accessibility for tourist will turn out exceptionally high. In the Adršpach-Teplice Rocks, despite the growth of length of hiking trails in recent years, a large part of the reserve is not available to tourists, which is assisted by numerous boulders and dense vegetation cover making it difficult to walk outside the official trails. On the other hand, the tourist traffic on two main sightseeing routes, starting at parking lots and railway stations, is so large that some passages in the rocks create significant congestion. At the peak tourist season, due to the large number of visitors, entry to main routes might be temporarily limited or even closed. These issues are related to the protection of both inanimate (sandstone landscapes) and animate nature (which benefits from specific conditions created among rocks). Erosion, trampling, littering or vandalism are typical problems reported from many protected areas, not only related to sandstones (particularly many works relating to these problems in Central Europe concern the Tatra Mountains, Pieniny and the Giant Mountains - see e.g. (Buchwał and Fidelus 2008; Hrnčiarová et al. 2018; Kasprzak 2005, 2006; Kolasińska et al. 2015)). Rogowski wrote about these problems in the context of the Table Mountains, referring mainly to the monitoring system of tourist traffic (Rogowski 2017, 2018a, 2018b). In the sandstone areas, the erosion of paths and stairs in the rocks and destruction of popular rock formations, especially those to which one can climb, is a big problem. Numerous forms of devastation of nature are also noticeable - scratching of inscriptions in sandstones, littering, trampling vegetation and destruction of devices that channel tourist traffic.

Another matter remains the way geoheritage is interpreted and tourists are provided with information about it, what is an issue analysed by many authors (e.g. (Badman 1994; Hose 1995, 2000, 2005b)). Among the analysed protected areas, the most extensive and targeted offer in this aspect can be found in the Table Mountains National Park, which can be proud of probably the oldest geological and geomorphological educational trail of the Sudetes and Poland. However, it requires modernisation. It is complemented by recently created panels that do not create any formal route, but are placed exactly in the places where one can admire the geological records of processes taking place at the bottom of the Cretaceous sea and during shaping of the contemporary Table Mountains. In the first case, this is an offer for a "casual geotourist" (see classification according to (Hose 2000), after (Chylińska 2018)), as it does not require prior substantive preparation. In the second-a certain knowledge and the ability to read geological maps is necessary, hence the information panels are intended more for a "dedicated 
geotourist", who have professional geoscience training or at least is familiar with the terminology of Earth sciences. In the Adršpach-Teplice Rocks National Nature Reserve in one of the two rock cities (Teplice), there is also an educational path that covers most of issues important for the natural environment of the area, discussing the geological structure, the way modern relief was created and its relationships with the water network and habitat conditions for plants and animals. The information provided in this case is directed to a "casual geotourist". It places geological issues in the context of general processes taking place in this area. What surprises, is the lack of similar facilities in the Adršpach Rock City, as well as very limited activities in this matter in the Prachov Rocks, although many objects and phenomena worth making known to geotourists occur also there. On the other hand, the Prachov Rocks are part of the Bohemian Paradise, where geology is explained in many other places; however, some tourist visit only this nature reserve, as it is probably the most famous in the region. It seems crucial to discuss phenomena and processes on specific examples that tourists can see from the trail. This can be done both in case of larger scale processes (e.g. the process of weathering a sandstone slab up to the formation of a rock city shown using examples of rock bastions of varying degrees of destruction) and smaller phenomena (discussing the ways of microforms, e.g. honeycomb weathering, creation on a sandstone surface in the places where these forms occur). These assumptions are best accomplished by the panels "Geoattractions of the Table Mountains" and the nature trail in the Teplice Rock City. Moreover, usage of online applications, providing geological and geotouristic information, also allows it.

\section{Conclusions}

The period of political transformation in Poland and the Czech Republic had an impact on many elements of the functioning of both states, also on matters of nature conservation and ways it is made accessible for tourism purposes, including the creation of tourist trails. The examples presented in the paper proved that a number of factors affect the development and management of the network of tourist trails (compare Table 1). In the case of the protected areas analysed, the systemic transformation in Central Europe played an important role, which resulted in changes in nature protection (the emergence of new protected areas, changes in the accessibility of existing ones) or the character of tourism. In each case, however, local factors were still important. Among these factors can be mentioned: landowners' decisions (Prachov Rocks), location near national borders (Table Mountains), activity of local authorities, tour operators (Adršpach-Teplice Rocks) and societies (especially in the case of marking trails), development of tourist facilities and its changes (mostly Prachov Rocks and Table Mountains), changes in area accessibility
(Prachov Rocks, Table Mountains) and network of paths possible to mark a trail (Prachov Rocks). It should also be remembered that all hiking trails in the Czech Republic are designed and marked by the association Club of Czech Tourists. In Poland, the situation is similar and the Polish Tourist and Sightseeing Society plays a key role here, but the exception are the areas of national parks, where the trails are designated exclusively by the park's authorities. So the size of the network of routes and its coherence may also be influenced by the differentiated activity of these entities. In general, however, their actions correspond, on one hand, with the needs of tourists, and on the other - with the requirements of environmental protection (as much as possible).

Referring to the elements of graph theory included in the paper, it is worth emphasising that the development of the network is not always associated with the increase of its cohesion, especially in areas with diversified sculpture, where it is not possible to designate as many new routes as one likes. As a result, trails spread from nodes (intersections) most often in three, not in four or more directions, what results in lower values of graph coefficients describing the cohesion of the network. This is true both in the case of the AdršpachTeplice Rocks, where the network was the most coherent in the period when it was limited to the greatest extent, and in the Table Mountains, where hiking trails formed the most coherent network before transformations, when only several routes were marked in this mountain range. So, the graph theory cannot be applied easily to tourist trails networks, especially when a dissected landscape is analysed. Similar results were achieved in works by Kołodziejczyk $(2018,2019)$ or Krakowiak (1997). A simple but very helpful indicator illustrating the development of the network is the density of tourist trails per square kilometre.

Open Access This article is licensed under a Creative Commons Attribution 4.0 International License, which permits use, sharing, adaptation, distribution and reproduction in any medium or format, as long as you give appropriate credit to the original author(s) and the source, provide a link to the Creative Commons licence, and indicate if changes were made. The images or other third party material in this article are included in the article's Creative Commons licence, unless indicated otherwise in a credit line to the material. If material is not included in the article's Creative Commons licence and your intended use is not permitted by statutory regulation or exceeds the permitted use, you will need to obtain permission directly from the copyright holder. To view a copy of this licence, visit http://creativecommons.org/licenses/by/4.0/.

\section{References}

Adamovič J, Mikuláš R, Cílek V (2006) Sandstone districts of the Bohemian Paradise: emergence of a romantic landscape. GeoLines 21:1-65 
Adams JQ (2016) Letters on Silesia/Listy o Śląsku. Muzeum Śląskie, Katowice

Alexandrowicz Z (1970) Skałki piaskowcowe w okolicy Ciężkowic nad Biała [Sandstone rocks in the vicinity of Ciężkowice on the Biała river]. Ochrona Przyrody 35:281-335 (in Polish)

Alexandrowicz Z (2006) Framework of European geosites in Poland. Nat Conserv 62(5):63-87

Alexandrowicz Z (2008) Sandstone rocky forms in Polish Carpathians attractive for education and tourism. Prz Geol 56(8/1):680-687

Badman T (1994) Interpreting earth science sites for the public. In: O'Halloran D, Green C, Harvey M et al (eds) Geological and landscape conservation. Geological Society, pp 429-432.

Balatka B, Sládek J (1984) Typizace reliéfu kvádrových pískovců české křídové pánve [Relief classification of the squared sandstones of the Bohemian Cretaceous Basin]. Academia, Praha (in Czech)

Bartuś T, Mastej W, Łodziński M (2009) Geotourist attractions of the Central Sudetic Geostrada. Geoturystyka 19:43-60

Baumgart W (1940) Goethe und Schlesien [Goethe and Silesia]. Schlesienbändchen 14. Schlesien-Verlag, Breslau (Wroclaw) (in German)

Bayfield N (1973) Use and deterioration of some Scottish hill paths. J Appl Ecol 10:635-644

Bičík J (2001) Postavení, změny a perspektivy druhého bydlení v Česku [State, changes and perspectives of the second housing in the Czech Republic]. In: Fialová D, Vágner J (eds) Druhé bydlení v Česku [Second housing in the Czech Republic]. Univerzita Karlova, Př́rodovědecká fakulta, katedra sociální geografie a regionálního rozvoje, Prague, pp 25-41 (in Czech)

Briedenhann J, Wickens E (2004) Tourism routes as a tool for the economic development of rural areas-vibrant hope or impossible dream? Tour Manag 25:71-79

Bruthans J, Soukup J, Vaculikova J, Filippi M, Schweigstillova J, Mayo AL, Masin D, Kletetschka G, Rihosek J (2014) Sandstone landforms shaped by negative feedback between stress and erosion. Nat Geosci 7(8):597-601

Buchwał A, Fidelus J (2008) The development of erosive and denudational landforms on footpaths sections in the Babia Góra massif and the Western Tatras. Geomorphologia Slovaca et Bohemica 8(2):14-24

Čech S, Gawlikowska E (1999) Góry Stołowe. Mapa geologicznoturystyczna w skali 1:50000 [Table Mountains. Geological-tourist map in scale 1:50000]. Państwowy Instytut Geologiczny, Český Geologický Ústav, Warsaw, Prague (in Polish)

Chmal H (2010) Johann Wolfgang Goethe (1949-1832)—przyrodnik [Johann Wolfgang Goethe (1949-1832) - the naturalist]. Czasopismo Geograficzne 81(3):173-185 (in Polish)

Chylińska D (2018) The role of the picturesque in geotourism and iconic geotourist landscapes. Geoheritage. https://doi.org/10.1007/s12371018-0308-x

Cílek V, Kopecký J (eds) (1998) Pískovcový fenomén: klima, život a relief [Sandstone phenomenon: climate, life and relief]. Česká speleologická společnost, Nakladatelství Zlatý kůň, Prague, Broumov (in Czech)

Cole D (1991) Changes on trails in the Selway-Bitterroot Wilderness, Montana, 1978-89. Intermountain Research Station, Forest Service, United States Department of Agriculture, Ogden, UT

Cole D (1995) Experimental trampling of vegetation: I. Relationship between trampling intensity and vegetation response. J Appl Ecol 32(1):203-214

Cole D, Bayfield N (1993) Recreational trampling of vegetation: standard experimental procedures. Biol Conserv 63:209-215

Cole D, Trull S (1992) Quantifying vegetation response of recreational disturbance in the North Cascades, Washington. Northwest Sci 66(4):229-236
Cwojdziński S, Pacuła J, Stachowiak A (2011) Geostrada Sudeckanowa forma geoturystyki w Sudetach [Sudetic Georoute - new form of geotourism in Sudetes]. Prz Geol 59:510-535 (in Polish)

Czudek Tet al (1972) Geomorfologické členění ČSR [Geomorphological regionalisation of the Czechoslovakian Republic]. Studia Geographica, sv. 23, Brno (in Czech)

Dale D, Weaver T (1974) Trampling effects on vegetation of the trail corridors of north Rocky Mountains forests. J Appl Ecol 11:767772

David P, Soukup V (2004) Bohemian Paradise, with map atlas. Prague.

Dołzbłasz S (2017) Transborder tourism in the Polish-Czech borderlands. In: Hall D (ed) Tourism and geopolitics: issues and concepts from Central and Eastern Europe. CABI, Wallingford-Boston, pp 163177

Dronka T, Figiel N, Stasiak A, Śledzińska J, Włodarczyk B (2014) Zasady tworzenia szlaków turystycznych [Rules for creating tourist trails]. In: Stasiak A, Śledzińska J, Włodarczyk B (eds) Szlaki turystyczne — od pomysłu do realizacji [Tourist trails - from the idea to the implementation]. Wydawnictwo PTTK "Kraj", Warsaw, pp 183-211 (in Polish)

Dudziak T, Potocki J (1995) Rozwój sieci szlaków turystycznych w Sudetach [The development of tourist trails in Sudetes]. Ślaski Labirynt Krajoznawczy 7:99-119 (in Polish)

Duszyński F, Migoń P (2015) Boulder aprons indicate long-term gradual and noncatastrophic evolution of cliffed escarpments, Stołowe Mts, Poland. Geomorphology 250:63-77

Duszyński F, Jancewicz K, Kasprzak M, Migoń P (2017) The role of landslides in downslope transport of caprock-derived boulders in sedimentary tablelands, Stołowe Mts, SW Poland. Geomorphology 295:84-101

ExpressMap (2007) Sudety Wschodnie: mapa laminowana 1:120000 [Eastern Sudetes: laminated map 1:120000]. Wydawnictwo Kartograficzne ExpressMap Sp. z o.o., Warsaw (in Polish)

Fialová D, Vágner J (eds) (2001) Druhé bydlení v Česku [Second housing in Czechia]. Univerzita Karlova, Př́rodovědecká fakulta, katedra sociální geografie a regionálního rozvoje, Prague (in Czech)

Fidelus J (2008) Rola ruchu turystycznego w przekształcaniu ścieżek i dróg turystycznych na obszarze Tatrzańskiego Parku Narodowego [The role of tourist traffic in landform transformations in the Tatra National Park]. Prace Geograficzne 120:19-29 (in Polish)

Fidelus J (2010) Porównanie skutków przekształceń rzeźby pod wpływem antropopresji w polskiej i słowackiej części Tatr Zachodnich [Comparing the effects of relief transformations due to anthropogenic impact in Polish and Slovak parts of the Western Tatra Mountains]. Prądnik. Prace i Materiały Muzeum im. prof. Władysława Szafera 20:185-196 (in Polish)

Fidelus J (2014) Slope transformation within tourist footpaths in the Western Tatra Mountains. Studia Geomorphologica CarpathoBalcanica 47(1):19-30

Geodézie On Line (2011a) Chráněná krajinná oblast Broumovsko: turistická a cykloturistická mapa 1:25000 [Broumovsko Area of Protected Landscape: tourist and cyclotourist map 1:25000]. Geodézie On Line, Česká Lipa (in Czech).

Geodézie On Line (2011b) Chráněná krajinná oblast Český ráj: cykloturistická a turistická oboustranná mapa 1:25000 [Bohemian Paradise Protected Landscape Area: cyclotourist and tourist twoside map 1:25000]. Geodézie On Line, Česká Lipa (in Czech).

Gilejko L (2009) Polska transformacja - próba bilansu i nowa perspektywa [Polish transformation - assessment of results and a new perspective]. Res Humana 3/2009:17-21 (in Polish)

Gross JL, Yellen J, Anderson M (2018) Graph theory and its applications. https://doi.org/10.1201/9780429425134

Guldan A (2006) O značkovaných turistických chodníkoch. Pre mladých aj starších turistov a priatelov prírody [About marked hiking trails. For young and old tourists and friends of nature]. Klub slovenských turistov, Bratislava (in Slovak) 
Gutzerová N, Herben T (1998) Mikroklima a vegetace pískovcových skalních měst [Microclimate and vegetation of sandstone rock towns]. In: Cílek V, Kopecký J (eds) Pískovcový fenomén: klima, život a relief [Sandstone phenomenon: climate, life and relief]. Česká speleologická společnost, Nakladatelství Zlatý kůn̆, Prague, Broumov, pp 25-32 (in Czech)

Härtel H, Cílek V, Herben T, Jackson A, Williams R (eds) (2007) Sandstone landscapes. Akademia, Prague

Hose TA (1995) Selling the story of Britain's Stone. Environ Int 102:16 17

Hose TA (2000) Geological interpretation and geoconservation promotion for tourists. In: Barretino D, Wimbledon WAP, Gallego E (eds) Geological heritage: its conservation and management. Sociedad Geologica de Espana/Instituto TechnologicoGeoMinero de Espana/ProGEO, Madrid, pp 127-146

Hose TA (2005a) Geotourism: appreciating the deep time of landscapes. In: Novelli M (ed) Niche tourism: contemporary issues, trends and cases. Elsevier Butterworth-Heinemann, Oxford, pp 27-37

Hose TA (2005b) Geotourism and interpretation. In: Dowling RK, Newsome D (eds) Geotourism. Sustainability, impact, and management. Elsevier Butterworth-Heinemann, Oxford, pp 221-241

Hose TA (2012) 3G's for modern geotourism. Geoheritage 4(1-2):7-24

Hrnčiarová T, Kenderessy P, Špulerová J, Vlachovičová M, Piscová V, Dobrovodská M (2018) Status and outlook of the hiking trails in the central part of the Low Tatra Mountains in Slovakia between 1980 1981 and 2013-2014. J Mt Sci 15(8):1615-1632

Illner M (1996) Post-communist transformation revisited. Sociologický časopis/Czech Sociol Rev 4(2):157-169

Juda J, Belisová N, Nagel R, Marková I, Vařilová Z (2012) Průvodce naučnou stezkou "Okolím Pravčické brány" [Guide to the nature trail "Around Pravčická gate"]. Správa NP České Švýcarsko, Krasná Lípa (in Czech)

Kartografie (1975) Teplicko-adršpašské skály: soubor turistických map [Teplice-Adršpach Rocks: set of tourist maps]. Kartografie, Prague (in Czech)

Kartografie (1986) Prachovské skaly - mapa ze souboru turistických map v měŕitku 1:10000 [Prachov Rocks: map with set of tourist maps 1: 10000]. Kartografie, Prague (In Czech)

Kartografie Praha (1991) Teplicko-adršpašské skály a Broumovské stěny: soubor turistických map [Teplice-Adršpach Rocks and Broumov Walls: set of tourist maps]. Kartografie Praha, Prague (in Czech)

Kartografie Praha (1993) Prachovské skály: soubor turistických map 1: 10000 [Prachov Rocks: set of tourist maps 1:10000]. Kartografie Praha, Prague (in Czech)

Kasprzak M (2005) Tempo degradacji powierzchni dróg i ścieżek turystycznych w Karkonoszach Wschodnich [The degradation rate of tourist tracks in the East Karkonosze Mountains]. Opera Corcontica 42:17-30 (in Polish)

Kasprzak M (2006) Erozja wodna na drogach i ścieżkach turystycznych w Karkonoszach [Water erosion on tourist tracks and paths in the Karkonosze Mountains]. Przyroda Sudetów 9:179-190 (in Polish)

Kasprzak K, Skoczylas J (1993) Rozwój ochrony przyrody nieożywionej i ożywionej: historia i współczesność [The development of inanimate and animated nature conservation: history and the present]. Fundacja 'Warta', Poznan (in Polish)

Klaus V (2006) The economic transformation of the Czech Republic: challenges faced and lessons learned. Economic Development Bulletin 6. Available at: https://www.cato.org/publications/ economic-development-bulletin/economic-transformation-czechrepublic-challenges-faced-lessons-learned (accessed 15 July 2019).

Kluvánková-Oravská T, Chobotová V, Banaszak I, Slavikova L, Trifunovova S (2009) From government to governance for biodiversity: the perspective of Central and Eastern European transition countries. Environ Policy Gov 19:186-196

Kolasińska A, Adamski P, Ciapała S, Svajda J, Witkowski Z (2015) Trail management, off-trail walking and visitors impact in the Pieniny
Mts National Park (Polish Carpathians). Eco.mont. J Protected Mountain Areas Res Manag 7(1):26-36

Kołodziejczyk K (2014a) Rozwój sieci szlaków turystycznych wzdłuż granicy polsko-czeskiej w Sudetach w latach 1945-2013 [Development of a network of tourist trails along the Polish-Czech border in the Sudetes in the years 1945-2013]. Prace Geograficzne 136:81-101 (in Polish)

Kołodziejczyk K (2014b) Oferta turystycznych linii autobusowych przewożących rowery w Republice Czeskiej [Offer of tourist bus lines transporting bicycles in the Czech Republic]. Transport Miejski i Regionalny 11(2014):27-34 (in Polish)

Kołodziejczyk K (2015) Wzorce zagospodarowania szlaków turystycznych $\mathrm{w}$ górach średnich na wybranych przykładach europejskich [Patterns for the development of tourist trails in the high mountains on selected European examples]. Instytut Geografii i Rozwoju Regionalnego Uniwersytetu Wrocławskiego, Wroclaw (in Polish)

Kołodziejczyk K (2017a) Zmiany dostępności komunikacyjnej ziemi kłodzkiej wobec jej funkcji turystycznych - wybrane zagadnienia [Changes in the communication accessibility of the Kłodzko region towards its tourist functions - selected issues]. Transport Miejski i Regionalny 4(2017):18-25 (in Polish)

Kołodziejczyk K (2017b) Wpływ zmian oferty komunikacji autobusowej na dostępność atrakcji turystycznych na ziemi kłodzkiej [The impact of changes in the bus service offer on the availability of tourist attractions in the Kłodzko region]. Transport Miejski i Regionalny 5(2017):5-11 (in Polish)

Kołodziejczyk K (2017c) Organizacja ruchu turystycznego w Parku Narodowym Czeska Szwajcaria [Organisation of tourist movement in the Czech Switzerland National Park]. Folia Turistica 43:9-43 (in Polish)

Kołodziejczyk K (2018) Sieć pieszych szlaków turystycznych w Parku Krajobrazowym Góry Izerskie w północnej Republice Czeskiej [Network of hiking trails in the Jizera Mountains Landscape Park in the northern Czech Republic]. Prace Geograficzne 152:83-104 (in Polish)

Kołodziejczyk K (2019) Networks of hiking tourist trails in the Krkonoše (Czech Republic) and Peneda-Gerês (Portugal) national parkscomparative analysis. J Mt Sci 16(4):725-743. https://doi.org/10. 1007/s11629-018-5228-3

Kowalczyk A (1994) Geograficzno-społeczne uwarunkowania zjawiska "drugich domów" [Geographical and social conditions of the "second homes" phenomenon]. Uniwersytet Warszawski, Warsaw (in Polish)

Kowalczyk A (2009) Zagospodarowanie turystyczne obszarów chronionych (na przykładzie Afryki Południowej) [Tourist infrastructure of protected areas (on the example of South Africa)]. Prace i Studia Geograficzne 42:15-58 (in Polish)

Kowalczyk A, Derek M (2010) Zagospodarowanie turystyczne [Tourist infrastructure]. Wydawnictwo Naukowe PWN, Warsaw (in Polish)

Krakowiak B (1997) Zagospodarowanie turystyczne karpackich parków narodowych [Tourist infrastructure in the Carpathian national parks]. Turyzm 7(2):25-44 (in Polish)

Královéhradecký kraj (2015) Skalne miasta pogranicza kłodzkiego. Královéhradecký kraj, freytag \& berndt, Prague (in Polish)

Kubalíková L (2018) Czech Republic: the planning and management of geotourism's hidden resources. In: Dowling R, Newsome D (eds) Handbook of geotourism. Edward Elgar Publishing Limited, Cheltenham, pp 417-432

Lijewski T, Mikułowski B, Wyrzykowski J (2002) Geografia turystyki Polski [Tourism geography of Poland]. Polskie Wydawnictwo Ekonomiczne, Warsaw (in Polish)

Mapa turystyczna (n.d.) Mapa szlaków turystycznych w górach [Map of tourist trails in the mountains]. Available at: https://mapaturystyczna.pl/ (accessed 22 October 2018) (in Polish) 
Marek A (2013) Atrakcje turystyczne Czeskiego Raju [Tourist attractions of the Bohemian Paradise]. Słupskie Prace Geograficzne 10:73-87 (in Polish)

Marková I (2013) Bryophytes in the Czech sandstone landscape areas. In: Migoń P, Kasprzak M (eds) Sandstone landscapes: diversity, ecology and conservation, Department of Geography and Regional Development, University of Wroclaw, Wroclaw, pp 111-116

Martynowski Z, Mazurski KR (1988) Sudety: Ziemia Kłodzka i Góry Opawskie [Sudetes: Kłodzko Land and Opawskie Maountains]. Wydawnictwo Sport i Turystyka, Warsaw (in Polish)

Matczak A (1986) Budownictwo letniskowe w strefie podmiejskiej Łodzi [Recreation houses in the suburban area of Łódź]. Folia Geographica 7:137-165 (in Polish)

Maziarz P, Rejman K, Kwiatkowski C, Majcher D (2017) The selected factors influencing tourism and recreation development in the Tatra Mountains. World Sci News 72:637-656

Mazurski KR (2012) Historia turystyki sudeckiej [History of tourism in Sudetes]. Oficyna Wydawnicza "Wierchy", COTG PTTK, Cracow (in Polish)

Mertlík J, Adamovič J (2016) Bohemian Paradise: sandstone landscape in the foreland of a major fault. In: Pánek T, Hradecký J (eds) Landscapes and landforms of the Czech Republic. Springer, Dordrecht, pp 195-208

Migoń P (2012a) Geoturystyka [Geotourism]. Wydawnictwo Naukowe PWN, Warsaw (in Polish)

Migoń P (2012b) Geographical setting and general landscape. In: Kasprzak M, Migoń P (eds) Góry Stołowe: geology, landforms, vegetation patterns and human impact. Department of Geography and Regional Development, University of Wroclaw, Wroclaw, pp 57

Migoń P (2012c) Landforms and landform evolution. In: Kasprzak M, Migoń P (eds) Góry Stołowe: geology, landforms, vegetation patterns and human impact. Department of Geography and Regional Development, University of Wroclaw, Wroclaw, pp 11-19

Migoń P (2012d) Nature conservation. In: Kasprzak M, Migoń P (eds) Góry Stołowe: geology, landforms, vegetation patterns and human impact. Department of Geography and Regional Development, University of Wroclaw, Wroclaw, p 34

Migoń P (2012e) Tourism. In: Kasprzak M, Migoń P (eds) Góry Stołowe: geology, landforms, vegetation patterns and human impact. Department of Geography and Regional Development, University of Wroclaw, Wroclaw, pp 35-36

Migoń P (2016) Rediscovering geoheritage, reinventing geotourism: 200 years of experience from the Sudetes, Central Europe. In: Hose TA (ed) Appreciating physical landscapes: three hundred years of geotourism. The Geological Society, London, pp 215-228

Migoń P, Pijet-Migoń E (2006) Czeski Raj-nowy europejski geopark [The Bohemian Paradise - a new European geopark]. Geoturystyka 4(7):21-32 (in Polish)

Migoń P, Duszyński F, Goudie A (2017) Rock cities and ruiniform relief: forms, processes, terminology. Earth Sci Rev 171:78-104

Migoń P, Różycka M, Jancewicz K, Duszyński F (2018) Evolution of sandstone mesas: following landform decay until death. Prog Phys Geogr 42(5):588-606

Mika M (2003) Environmental impact of tourism development in reception areas in Poland and methods of controlling them. Prace Geograficzne 111:129-141

Mitchell AJ, Uličný D, Hampson GJ, Allison PA, Gorman GJ, Piggott MD, Wells MR, Pain CC (2010) Modelling tidal current-induced bed shear stress and palaeocirculation in an epicontinental seaway: the Bohemian Cretaceous Basin, Central Europe. Sedimentology 57(2):359-388

Newsome D, Dowling RK (eds) (2010) Geotourism: the tourism of geology and landscapes. Goodfellow, Oxford
Nováková J, Poulíčková A (2004) Moss diatom (Bacillariophyceae) flora of the Nature Reserve Adršpašsko-Teplické Rocks (Czech Republic). Czech Phycol 4:75-86

Olympia (1982) Československo: průvodce [Czechoslovakia: guide]. Olympia, Praha (in Czech)

Państwowe Przedsiębiorstwo Wydawnictw Kartograficznych (1974) Góry Stołowe: mapa turystyczna [Table Mountains: tourist map]. Państwowe Przedsiębiorstwo Wydawnictw Kartograficznych, Warsaw (in Polish)

Państwowe Przedsiębiorstwo Wydawnictw Kartograficznych (1985) Góry Stołowe: mapa turystyczna [Table Mountains: tourist map]. Państwowe Przedsiębiorstwo Wydawnictw Kartograficznych, Warsaw, Wroclaw (in Polish)

Park Narodowy Gór Stołowych (n.d.) Didactic routes. Available at: http:// www.pngs.com.pl/gb/edukacja/eduk1.html (accessed 19 November 2018).

Pavlínek P, Pickles J (2005) Environmental transitions: transformation and ecological defence in Central and Eastern Europe. Routledge, London, New York

Petronis MS, Brister AR, Rapprich V, van Wyk de Vries B, Lindline J, Misurec J (2015) Emplacement history of the Trosky basanitic volcano (Czech Republic): paleomagnetic, rock magnetic, petrologic, and anisotropy of magnetic susceptibility evidence for lingering growth of a monogenetic volcano. J Geosci 60(3):129-147

Petronis M, Valenta J, Rapprich V, Lindline J, Heizler M, van Wyk de Vries B, Shields S, Balek J, Fojtíková L, Tábořík P (2018) Emplacement history of the Miocene Zebín Tuff Cone (Czech Republic) revealed from ground geophysics, anisotropy of magnetic susceptibility, paleomagnetic, and 40Ar/39Ar geochronology data. Geochem Geophys Geosyst 19(10):3764-3792

Pilous V, Pišl M, Pojkar M, Švec J, Houba M, Staněk J, Horák J (1982) Český ráj a Podkrkonoší [Bohemian Paradise and the Giant Mountains Foothills]. Olympia, Praha (in Czech)

Plan (2007) Góry Stołowe: mapa turystyczna 1:30000 [Table Mountains: tourist map 1:30000]. Wydawnictwo Kartograficzne Plan, Jelenia Góra (in Polish).

Potocki J (2004) Rozwój zagospodarowania turystycznego Sudetów od połowy XIX w. do II wojny światowej [The development of the tourism infrastructure of the Sudetes from the mid-19th century to the Second World War]. Wydawnictwo Turystyczne Plan, Jelenia Góra (in Polish)

Potocki J (2010) Pressure on natural environment in major tourist locations of the Karkonosze Mts. in light of demographic trends and expansion of the tourist function of the region. Opera Corcontica 47(Suppl. 1):277-282

Potocki J (2013) Kształtowanie sieci turystycznych szlaków pieszych w Sudetach po II wojnie światowej i jego ważniejsze uwarunkowania [Shaping the network of tourist walking trails in the Sudetes after the Second World War and its more important conditions]. In: Mateusiak A (ed) Zarys dziejów turystyki i przewodnictwa w Sudetach [Outline of the history of tourism and tourist guidance in the Sudetes]. Wydawnictwo AD REM, Jelenia Góra, pp 23-46 (in Polish)

Potrykowski M, Taylor Z (1982) Geografia transportu: zarys problemów, modeli i metod badawczych [Geography of transportation: basic problems, models and analytic methods]. PWN, Warsaw (in Polish)

Pulinowa M (2000) Ścieżka Skalnej Rzeźby w Górach Stołowych przewodnik po ścieżce dydaktycznej [Path of Rock Sculpture in the Table Mountains - guidebook for the didactic path]. Park Narodowy Gór Stołowych, Kudowa-Zdrój (in Polish)

Rapprich V, Cajz V, Kostak M, Pecskay Z, Ridkosil T, Raska P, Radon M (2007) Reconstruction of eroded monogenic Strombolian cones of Miocene age: a case study on character of volcanic activity of the Jicin Volcanic Field (NE Bohemia) and subsequent erosional rates estimation. J Geosci 52(3-4):169-180 
Rapprich V, Lisec M, Fiferna P, Závada P (2017a) Application of modern technologies in popularization of the Czech volcanic geoheritage. Geoheritage 9(3):413-420

Rapprich V, Shields S, Halodova P, Lindline J, van Wyk de Vries B, Petronis MS, Valenta $\mathrm{J}$ (2017b) Fingerprints of magma mingling processes within the Miocene Zebin tuff cone feeding system (Jicin Volcanic Field, Czech Republic). J Geosci 62(4):215-229

Rogowski M (2016) The potential of the Sudetes Mountains for the development of geotouristic products. Geotourism 3-4(46-47):5980

Rogowski M (2017) Mountain hiking in the Stołowe Mountains National Park. Tourism 27(2):89-97

Rogowski M (2018a) System Monitoringu ruchu turystycznego (SMrt) w Parku Narodowym Gór Stołowych dla potrzeb badań przestrzeni turystycznej [Monitoring System of tourist traffic (SMtt) in the Stołowe Mountains National Park in the research on tourism spaces]. Prace i Studia Geograficzne 63(3):153-172 (in Polish)

Rogowski M (2018b) Use of Monitoring System of Tourist Traffic (MSTT) in Stolowe Mts. National Park for visitors description. Econ Environ 65:87-98

Roovers P, Verheyen K, Hermy M, Gulinck H (2004) Experimental trampling and vegetation recovery in some forest and heathland communities. Appl Veg Sci 7:111-118

Roszkowski W (2003) Najnowsza historia Polski 1980-2002 [The recent history of Poland 1980-2002]. Świat Książki, Warsaw

Schlik JM, s.r.o. (n.d.) Prachovské skály. Available at: https://www. prachovskeskaly.com/en/ (accessed 6 November 2018)

Seznam.cz (n.d.) Mapy [Maps]. Available at: https://en.mapy.cz/ (accessed 21 October 2018)

SHOCart (2008) Orlické hory, Góry Stołowe: turistická mapa 1:50000 [Orlicke Mountains, Table Mountains: tourist map 1:50000]. SHOCart, Vizovice (in Czech)

Škvor J (1982) Makroreliéf a mezoreliéf Prachovských skal [Macro-relief and mezo-relief of the Prachov Rocks]. Acta Univ Carolinae, Geogr 17:61-79 (in Czech)

Słomka T, Doktor M (2011) Katalog obiektów geoturystycznych w obrębie pomników przyrody i rezerwatów przyrody nieożywionej [Catalogue of geotourist sites in areas of abiotic nature monuments and reserves]. Prz Geol 59(4):335-339 (in Polish)

Słomka T, Kicińska-Świderska A, Doktor M, Joniec A (2006) Katalog obiektów geoturystycznych w Polsce [The catalogue of geotourist sites in Poland]. Akademia Górniczo-Hutnicza, Cracow (in Polish)

Stachowiak A, Cwojdziński S, Ihnatowicz A, Pacuła J, Mrázová Š, Skácelová D, Otava J, Pecina V, Rejchrt M, Skácelová Z, Večeřa J (2013) Sudetes Georoute. Polish Geological Institute - National Research Institute, Czech Geological Survey, Warsaw, Prague

Stasiak A, Śledzińska J, Włodarczyk B (2014) Funkcje szlaków turystycznych [Functions of tourist trails]. In: Stasiak A, Śledzińska J, Włodarczyk B (eds) Szlaki turystyczne - od pomysłu do realizacji [Tourist trails-from the idea to the implementation]. Wydawnictwo PTTK “Kraj”, Warsaw, pp 173-182 (in Polish)

Styperek J (2001) Piesze szlaki turystyczne w polskich parkach narodowych [Hiking tourist trails in Polish national parks]. Turyzm 11(1):25-37 (in Polish)

Styperek J (2002) Linearne systemy penetracji rekreacyjnej [Linear systems of recreational penetration]. Wydawnictwo Naukowe Bogucki, Poznan (in Polish)

Taafee EJ, Gauthier HL (1973) Geography of transportation. Prentice Hall, Englewood Cliffs

Taczanowska K, Gonzalez LM, Garcia-Masso X, Muhar A, Brandenburg C, Toca-Herrera J (2014) Evaluating the structure and use of hiking trails in recreational areas using a mixed GPS tracking and graph theory approach. Appl Geogr 55:184-192
Taczanowska K, Bielański M, Gonzalez LM, Garcia-Masso X, TocaHerrera J (2017) Analyzing spatial behavior of backcountry skiers in mountain protected areas combining GPS tracking and graph theory. Symmetry 9(12):317. https://doi.org/10.3390/sym 9120317

Uličný D (2001) Depositional systems and sequence stratigraphy of coarse-grained deltas in a shallow-marine, strike-slip setting: the Bohemian Cretaceous Basin, Czech Republic. Sedimentology 48(3):599-628

Uličný D, Laurin J, Čech S (2009) Controls on clastic sequence geometries in a shallow-marine, transtensional basin: the Bohemian Cretaceous Basin, Czech Republic. Sedimentology 56(4):10771114

Vágner J (2001) Vývoj druhého bydleni v Česku [Development of second housing in the Czech Republic]. In: Fialová D, Vágner J (eds) Druhé bydlení v Česku [Second housing in the Czech Republic]. Univerzita Karlova, Př́rodovědecká fakulta, katedra sociální geografie a regionálního rozvoje, Prague, pp 42-54 (in Czech)

Vařilová Z, Zvelebil J, Přikryl R, Navrátil T, Vlčko J, Beneš V, Hubatka F (2013) In: Migoń P, Kasprzak M (eds) Stability complex deterioration of a Rock Arch - case history of the Pravčická brána, Sandstone landscapes: diversity, ecology and conservation, Department of Geography and Regional Development, University of Wroclaw, Wroclaw, pp 202-209

Vítek J (1980) Pseudokrasové tvary v Prachovských skalách [Pseudokarst forms in the Prachov Rocks]. Československý kras 31:45-56 (in Czech)

Vítek J (2016) Adršpach-Teplice Rocks and Broumov Cliffs-Large Sandstones Rock Cities in the Central Europe. In: Pánek T, Hradecký J (eds) Landscapes and landforms of the Czech Republic. Springer, Dordrecht, pp 209-220

Vojenský kartografický ústav (1993) Adršpašsko-teplické skály a Ostaš: turistická mapa 1:25000 [Adršpach-Teplice Rocks and Ostaš Mountain: tourist map 1:25000]. Vojenský kartografický ústav, Harmanec (in Czech)

Vystoupil J, Šauer M (2012) Geography of tourism of the Czech Republic. In: Wyrzykowski J, Widawski K (eds) Geography of tourism of Central and Eastern Europe countries. Institute of Geography and Regional Development, University of Wroclaw, Wroclaw, pp 103-139

Wojewoda J (2008) Budowa geologiczna obszaru PNGS [Geological structure of the Table Mountains National Park area]. In: Witkowski A, Pokryszko B, Ciężkowski W (eds) Przyroda Parku Narodowego Gór Stołowych [Nature of the Table Mountains National Park]. Wydawnictwo Parku Narodowego Gór Stołowych, Kudowa-Zdrój, pp 24-37 (in Polish)

Wojewoda J (2011) Geoatrakcje Gór Stołowych - przewodnik geologiczny po Parku Narodowym Gór Stołowych [Geoattractions of the Table Mountains-geological guidebook for the Table Mountains National Park]. Park Narodowy Gór Stołowych, Wrocław (in Polish)

Wojewoda J (2012) Geology and geological history. In: Kasprzak M, Migoń P (eds) Góry Stołowe: geology, landforms, vegetation patterns and human impact. Department of Geography and Regional Development, University of Wroclaw, Wroclaw, pp 7-11

Wojewoda J (2013a) Mapa geoatrakcji krainy Gór Stołowych i Broumovskich Stěn [Map of geoattractions of the Table Mountains and Broumovské stěny region]. Wydawnictwo Turystyczne "Plan", Gmina Radków, Jelenia Góra, Radków (in Polish)

Wojewoda J (ed) (2013b) Geoatrakcje okolic Radkowa [Geoattractions of Radków neighbourhood]. Gmina Radków, Radków (in Polish)

Ziolko K-H (1992) Goethes Schlesische Reise, Bad Windshein. 